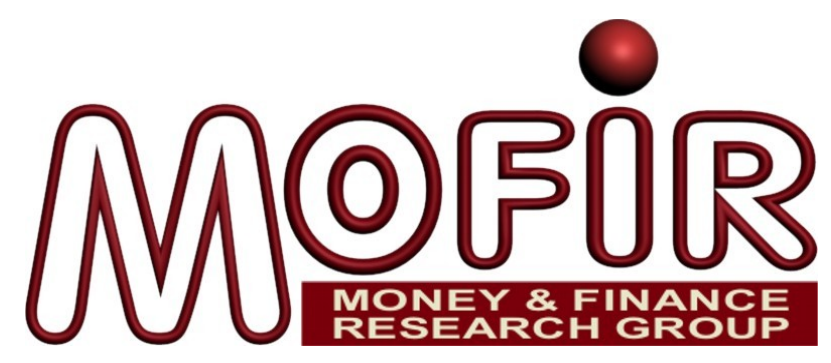

\title{
Foreign Banks and the Vienna Initiative: TuRning SinNERS INTO SAINTS?
}

\author{
RALPH DE HAAS \\ European Bank for Reconstruction and Development (EBRD) \\ YevgeniYa KoRniYenKo \\ Bank of England \\ Elena Loukoianova \\ International Monetary Fund \\ Alexander Pivovarsky \\ European Bank for Reconstruction and Development (EBRD)
}

MoFiR working paper $\mathrm{n}^{\circ} 62$

March 2012 


\title{
Foreign Banks and the Vienna Initiative: Turning Sinners into Saints?
}

\author{
Ralph De Haas, Yevgeniya Korniyenko, Elena Loukoianova, Alexander Pivovarsky*
}

This version: March 2012

\begin{abstract}
We use data on 1,294 banks in Emerging Europe to analyze how bank ownership and the so-called Vienna Initiative impacted credit growth during the 2008-09 crisis. As part of the Vienna Initiative western European banks signed country-specific commitment letters in which they pledged to maintain exposures and to support their subsidiaries in Emerging Europe. We show that in general both domestic and foreign banks sharply curtailed credit during the crisis, but that foreign banks that participated in the Vienna Initiative were relatively stable lenders. We find no evidence of negative spillovers from countries where banks signed commitment letters to countries where they did not.
\end{abstract}

JEL classification: C23, F36, G21, P34

Key words: Foreign banks, Vienna Initiative, financial crisis, state support

\footnotetext{
* De Haas and Pivovarsky are with the European Bank for Reconstruction and Development (EBRD), Korniyenko with the Bank of England, and Loukoianova with the International Monetary Fund (IMF). The authors would like to thank Bas Bakker, Erik Berglöf, Hans Degryse, Zuzana Fungáčová, Mark Griffiths, AnneMarie Gulde, Simon Johnson, Hannah Levinger, Elitza Mileva, Piroska M. Nagy, Katharina Pistor, Alberto F. Pozzolo, Jerome Vandenbussche, Neeltje Van Horen, Veronika Zavacka, Jeromin Zettelmeyer, and seminar participants at the Bank of England, EBRD, International Monetary Fund, Kyiv School of Economics, National Bank of Georgia, National Bank of Moldova, University of Tilburg, the $9^{\text {th }}$ ECB/Bundesbank Workshop on Emerging Markets, and the MoFiR Workshop on Banking (Ancona) for useful comments. Corresponding author: dehaasr@ebrd.com. The views expressed in this paper are the authors' and do not necessarily reflect those of the Bank of England, EBRD, or IMF.
} 


\section{Introduction}

The start of the transition process in 1989 heralded the large-scale entry of foreign banks into Emerging Europe. Western-European banks with saturated home markets were attracted to the transition region due to its scope for financial deepening and its ample growth potential. Policy makers and development institutions stimulated financial integration because of its presumed positive impact on the efficiency and stability of local banking systems. The empirical evidence that emerged over the next two decades suggests that foreign bank entry indeed stimulated competition and transferred know-how (Fries and Taci, 2005; Havrylchyk and Jurzyk, 2011) and that foreign banks were relatively stable credit sources during local financial turmoil (De Haas and Van Lelyveld, 2006).

The global financial crisis of 2008-09 put this model of intense cross-border banking to the test. The crisis was unique in that it emanated from the home markets of the banking groups operating in Emerging Europe. Although few of these large banks had direct U.S. sub-prime exposures, most of them were affected by the sharp reduction in interbank liquidity as of the second half of 2007. Banks started to deleverage both at home and abroad, a process that accelerated after the collapse of Lehman Brothers in September 2008 (Cetorelli and Goldberg, 2011; De Haas and Van Horen, 2012). It became increasingly uncertain whether multinational banks, now battered by problems elsewhere, would keep funding Eastern European customers through their local subsidiaries.

In response to these mounting pressures, Western governments supported various banks with guarantees as well as capital and liquidity injections towards the end of 2008. This alleviated concerns about a credit crunch 'at home' but did not reduce worries about a retrenchment of multinational banks from Emerging Europe. On the contrary, concerns were raised that government support came with 'strings attached'. Anecdotal evidence suggests that banks were indeed asked to focus on domestic lending (Kamil and Rai, 2010). For instance, French banks that received state support had to increase domestic lending by 3-4 per cent annually, while Dutch bank ING announced that it would lend US\$32 billion to Dutch borrowers in return for government support (World Bank, 2009, p. 70).

Tightening funding constraints and potentially biased government interventions raised concerns about an uncoordinated rush of banks out of Emerging Europe. Although most banks confirmed their commitment to the region during the early stage of the crisis, there was no formal policy framework or coordination mechanism in place to ensure these commitments were credible. The fear was that while it would be in the collective interest of banks to roll-over debt to Emerging Europe, the absence of a coordination mechanism could lead individual banks to withdraw, ultimately causing a 'run' on the region. The absence of agreements on how to share the burden of a defaulting subsidiary between the fiscal authorities in the home and host countries further exacerbated the risk of such a run. The accompanying decline or reversal in financial flows would not only have had dire consequences for 
local firms and households but also have led to large exchange-rate fluctuations and balance of payments problems.

In response to this institutional vacuum, the Austrian government and a number of multinational banks with high exposures to Emerging Europe started to engage in informal discussions towards the end of 2008. The goal of this 'Vienna Initiative' (VI) ${ }^{1}$ was to avoid collective action problems (Pistor, 2011) and to guarantee macroeconomic stability in Emerging Europe. Soon the VI meetings also included the main International Financial Institutions (IFIs), Ministries of Finance, central banks and bank regulators from the host and home countries of the main multinational banks, as well as the European Union and the European Central Bank.

In February 2009, the European Bank for Reconstruction and Development (EBRD), European Investment Bank (EIB), and the World Bank Group launched, within the context of the VI, a 'Joint IFI Action Plan in support of banking systems and lending to the real economy in Central and Eastern Europe'. The goal was to mobilize resources from these institutions to avert a banking crisis and support bank lending in the region. This support was integrated with IMF and European Union macrofinancial support programs to Bosnia and Herzegovina, Hungary, Latvia, Serbia, and Romania.

In return for these countries' commitment to keep their programs on track and for financial support under the Joint IFI Action Plan, a number of multinational banks signed country-specific commitment letters in which they pledged to maintain cross-border exposures and to continue to provide credit to firms and households. To do so, banks confirmed that they would keep subsidiaries adequately capitalized and provide them with sufficient liquidity. The VI thus developed into a comprehensive public-private partnership that combined macro-financial support by the IMF and the EU (a 'bail-out') with funding by various development institutions and a coordinated 'bail in' of private lenders.

Although a large-scale, uncoordinated withdrawal of banks from Emerging Europe did not materialize - and the VI can therefore be considered successful stricto sensu-as yet virtually no empirical analysis has been undertaken to assess its impact. ${ }^{2}$ No evidence is available on the role played by banks that were part of the VI versus those that were not. Likewise, for those multinational banks that were part of the VI, no comparison has been made between their lending behavior in countries where they signed commitment letters and countries where they did not. It also remains unclear whether signing commitment letters may have led to negative spillovers to other countries.

We employ a comprehensive bank-level dataset to fill these gaps in the literature. This is important as part of a thorough ex post evaluation of the VI and of the effectiveness of private-sector 'bail-ins' more generally. Our results also inform the current policy debate on similar initiatives against the

\footnotetext{
${ }^{1}$ The name later changed to European Bank Coordination Initiative. Levinger (2010) provides a historical overview of the VI.

${ }^{2}$ An exception is Cetorelli and Goldberg (2011) who on the basis of country-level data show that the decline in domestic bank lending was somewhat mitigated in the case of VI countries.
} 
background of the European sovereign debt crisis and its negative effect on international bank lending. With 'Vienna 2.0' in the making, it is important to have a better understanding of the effectiveness of the original Vienna Initiative.

Our empirical results indicate that both foreign and domestic banks sharply curbed credit growth during the crisis. While we find no impact of home-country state support packages on lending by foreign bank subsidiaries, we do find that banks that took part in the VI were relatively stable lenders. Moreover, VI banks did not retrench from non-VI countries in order to maintain exposures to countries where they signed commitment letters. If anything, participation in the VI led to positive rather than negative spillover effects to other countries. Finally, state-owned domestic banks were relatively stable lenders during the financial crisis.

These results allow us to contribute to three strands of the literature. First, we shed light on the implications of foreign bank entry for financial stability. Morgan, Rime and Strahan (2004) present a model in which multinational banks, by reallocating scarce capital across borders, absorb local shocks and transmit foreign shocks. The empirical literature finds evidence for both these roles. As regards the former, De Haas and Van Lelyveld (2006) find for emerging Europe that during past bouts of financial turmoil lending by foreign banks was more stable than lending by domestic banks. De Haas and Van Lelyveld (2010) present similar evidence for a broader set of countries and banks. In line with these findings, Dinger (2011) shows for Emerging Europe that the presence of multinational bank subsidiaries eases aggregate liquidity shortages during local crises.

As regards the role of multinational banks as shock transmitters, Peek and Rosengren $(1997,2000)$ demonstrate how the drop in Japanese stock prices in 1990 led Japanese bank branches in the United States to reduce lending. Schnabl (2012) analyzes how the 1998 Russian crisis spilled over to Peru as banks, including multinational bank subsidiaries, saw their foreign funding decline and had to reduce local lending. Chava and Purnanandam (2011) find similar evidence for US banks.

More recently, studies have started to assess whether multinational banks also transmitted the 2008-09 crisis across borders. De Haas and Van Lelyveld (2011) use an international dataset and find that multinational bank subsidiaries curtailed credit more aggressively than domestic banks. Domestic banks, which relied more on local deposits to fund credit growth, were better positioned to continue to lend. In line with this, Popov and Udell (2012) show how multinational banks transmitted the crisis to Emerging Europe and that the severity of shock transmission depended on the strength of parent banks' balance sheets. Ongena, Peydró, and Van Horen (2012) also focus on Emerging Europe. They use data on bank-firm relationships and show that not only foreign banks but also domestic banks that before the crisis had borrowed in the international wholesale markets, had to cut back lending more during the crisis. Yet, Barba Navaretti, Calzolari, Pozzolo, and Levi (2010) stress that multinational banks were a stabilizing force in Europe as they displayed a relatively stable loan-to-deposit ratio. 
Their analysis focuses on the years 2007-08 while, as we show in this paper, much of the reduction in lending only took place in 2009.

Second, our paper adds to the empirical literature on the impact of state support and state ownership on credit growth. Rose and Wieladek (2011) find for the recent crisis that foreign banks in the United Kingdom reduced their lending and increased interest rates when they were nationalized in their home country. Brei, Gambacorta, and Von Peter (2011) provide evidence that suggests that recapitalizations during the global financial crisis did not boost bank lending except for those banks with a capital ratio above a certain threshold. Micco and Panizza (2006) show that lending by state banks is less procyclical than lending by private banks as governments use state banks to smooth credit over the business cycle. Mian (2006) also finds that lending by state banks is less volatile in the face of macroeconomic shocks. Our paper provides a systematic comparison of foreign, private domestic, and state banks, to assess the impact of state ownership and state support during the recent crisis.

Third, our results provide evidence on the possible catalytic effect of crisis funding by an international lender of last resort like the IMF. A theoretical literature has developed to understand the conditions under which (limited) IMF funding, by acting as a seal of approval of a country's reform efforts, may help close an external funding gap and prevent a balance of payments crisis. Such a catalytic effect materializes if an IMF program nudges private creditors to roll over their commitments. Corsetti, Guimarães, and Roubini (2003) show how contingent support can reduce the range of economic fundamentals at which international investors find it optimal to withdraw from a country. In a similar vein, Morris and Shin (2006) demonstrate that catalytic finance works if it provides a country with incentives to keep up adjustment efforts without distorting creditors' roll-over decisions.

The empirical evidence on the effectiveness of contingent support is scarce. Cottarelli and Giannini (2002) conclude that IMF interventions typically result in only small increases in private capital. Corsetti and Roubini (2004) analyze a number of case studies and draw a slightly more positive conclusion. They highlight two relative success stories, Korea (1997) and Brazil (1999), where IMF lending was accompanied by roll-overs of interbank credit lines (in Korea short-term interbank lines were converted into longer and government-guaranteed bonds). In both cases -similar to the Vienna Initiative- roll-overs were neither completely voluntary nor uncoordinated (as in a 'pure' catalytic approach) and systems were put in place to monitor roll-over rates. The official sector organized a concerted private sector involvement to resolve collective action problems. $^{3}$

Our paper contributes to this literature by analyzing the impact of the combination of IMF funding and active creditor coordination. Instead of focusing on the narrow impact of the VI on the

\footnotetext{
${ }^{3}$ In 1998, Brazil initially limited its role to collecting data on rollover rates and sharing these with the IMF, without actively encouraging banks to maintain their cross-border lending. This soft monitoring without real 'bite' did not succeed in stemming a sharp reduction in international bank exposure to Brazil. A similarly soft monitoring arrangement in Turkey in 2002 proved to be a paper tiger as well (Roubini and Setser, 2004, p.150).
} 
participating countries' external funding gaps, we use bank-level data to analyze how banks' roll-over commitments ultimately influenced their lending across various VI and non-VI countries.

We proceed as follows. Section 2 provides more details about the Vienna Initiative after which Section 3 describes our data. Section 4 then explains our empirical methodology and Section 5 summarizes our empirical results. Section 6 concludes.

\section{The Vienna Initiative}

The VI came into being in the fall of 2008 when fears were growing about the vulnerability of Emerging Europe to withdrawals by multinational banks. ${ }^{4}$ Rapid credit growth during the pre-crisis period had left the private sector in many countries highly leveraged. A sharp reduction in multinational banks' funding to their subsidiaries would not only have caused a reduction in lending and asset prices, but most likely also have led to severe macroeconomic destabilization.

In November 2008, a number of pan-European banks with a large presence in Emerging Europe sent a letter to the European Commission, copying the EBRD and EIB, to call for a quick and coordinated response to the problems in Emerging Europe and, more specifically, to ensure sufficient funding for banks operating in the region. In response the VI was created as a coordination platform for multinational banks, their home and host country supervisors, fiscal authorities, the IMF, and development institutions to safeguard a continued commitment of parent banks to their subsidiaries. ${ }^{5}$ In addition, the European Commission ensured that banks benefiting from state support would not be forced to downsize their presence in Emerging Europe. In March 2009, an Emergency Summit of EU leaders confirmed that bank support packages at the national level should not lead to any restrictions on banks' eastern European subsidiaries.

On February $27^{\text {th }} 2009$ the EBRD, EIB, and the World Bank Group launched the 'Joint IFI Action Plan in support of banking systems and lending to the real economy in Central and Eastern Europe' with the objective "to support banking sector stability and lending to the real economy in crisis-hit Central and Eastern Europe". ${ }^{6}$ During Spring 2009, these institutions met several times with 17 banking groups that covered over 60 per cent of all banking assets in the region. The meetings led to a 'joint needs assessment' that resulted in financial support packages for individual banking groups. In aggregate, the institutions committed to a funding package of EUR 24.5 billion to support large crossborder banks. By end-September 2009, banks had received EUR 16.3 billion of IFI support in the

\footnotetext{
${ }^{4}$ Table A7 in the Annex provides a timeline of the Vienna Initiative.

${ }^{5}$ Impromptu coordination was necessary since burden sharing in the case of a failing European cross-border bank effectively depends on ex post negotiations between countries. Such improvised cooperation (Freixas, 2003) or ex post bargaining is prone to coordination failures.

${ }^{6}$ See http://www.ebrd.com/pages/news/press/2009/090227.shtml for details.
} 
form of senior loans, tier 1 and 2 capital, trade finance, facilities for small business loans, and syndicated loans. ${ }^{7}$

The Joint IFI Action Plan was embedded in a broader policy coordination framework by linking it to the IMF and EU stabilization programs. IMF programs were introduced in various countries when substantial amounts of foreign currency debt matured and external financing gaps opened up. Part of this debt was issued by multinational banks active in the region and insufficient roll-overs would have compromised the success of IMF-EU balance of payments stabilization programs. The authorities were wary not to substitute commercial funding with public sector money; the goal was to keep commercial banks 'bailed in' rather than bailed out. Debt roll-overs by commercial banks were therefore part of the burden-sharing agreements alongside macroeconomic support. Bank commitments consisted of strong mutual agreements that were nevertheless voluntary and not an explicit pre-condition for balance of payments support.

In five countries - Bosnia and Herzegovina, Hungary, Latvia, Romania, and Serbia - a total of 17 parent banks pledged, via so-called 'commitment letters', to maintain their overall exposures and to recapitalize subsidiaries for the duration of the IMF/EU programs. ${ }^{8}$ Importantly, the banks that signed differed by country as did the exact nature of the commitments. In the case of Latvia, the assumption was that Swedish banks would rollover at least 80 per cent of their lending to the country, the majority of which was to their own subsidiaries. In the case of Hungary, banks promised to ensure a "prudent capitalization of their subsidiaries" and to maintain at least 95 per cent of their September 2008 exposure. In Romania, the pledges were most concrete as banks promised to "increase the minimum capital adequacy ratio for each subsidiary from 8 to 10 percent" and to fully maintain their March 2009 exposure for the time of the IMF program. Also in Bosnia and Herzegovina and in Serbia banks committed to rollover 100 per cent of their exposure (as of December 2008) and to recapitalize subsidiaries if and when needed. Some of these commitments were reaffirmed later on in 2009. ${ }^{9}$ As the crisis subsided, pressure to maintain cross-border exposures was reduced and in some cases rollover commitments were lowered by early 2010 .

At the time concerns were expressed that the focus of the commitment letters on five core countries could tempt multinational banks to support these countries by withdrawing funds from countries without exposure commitments (such as Poland and the Czech Republic). Negative spillovers could have contributed to the cross-border transmission of the crisis (Keller, 2009; Mitra, Selowsky, and

\footnotetext{
${ }^{7}$ Progress Report 2009 (p. 4) and Final Report 2011 (p. 5). By end-December 2010, EUR 33.2 billion had been made available.

${ }^{8}$ Commitment letters were signed for Romania and Serbia in March 2009, Hungary in May 2009, Bosnia and Herzegovina in June 2009, and Latvia in September 2009. Belarus and the Ukraine had an IMF program but no commitment letters were signed.

${ }^{9}$ In Romania, parent banks ultimately did not maintain full exposures. With the exception of three banking groups, parent bank financing declined before the commitments were reaffirmed (see IMF, Romania: Letter of Intent and Technical Memorandum of Understanding, February 2010).
} 
Zalduendo, 2010). These concerns were alleviated by a number of informal agreements that extended the informal commitments of EBRD-supported banks to Emerging Europe as a whole. Moreover, in September 2009 and March 2010 so-called 'horizontal meetings' were held with various multinational banking groups as well as the relevant national and international authorities (see Table A5 in the Annex). The focus of these meetings was on lending to the region as a whole rather than the five countries with an IMF/EU program and explicit exposure commitments.

\section{Data and descriptive statistics}

Our main data consists of a panel of balance sheet and income statement data for 1,294 banks in Emerging Europe during 1999-2009. ${ }^{10}$ The source is Bureau van Dijk's BankScope database and all data are denominated in US dollars to ensure comparability across banks. We disregard banks for which we have less than three consecutive years of data. The panel is unbalanced as we do not have information for each bank in each year. For the crisis year 2009 the dataset contains 1,098 banks. We combine these data with macroeconomic information from the IMF International Financial Statistics.

In addition, we hand-collect information on crisis-related government support to banks in both home and host countries. We take this information from various publications by the European Commission ${ }^{11}$ and IMF, Reuters news service, and bank websites. We capture support in the form of capital injections, bank-specific guarantees, and asset sales to the government. For each bank we also analyze whether one or several of the three main development institutions operating in Emerging Europe - the EBRD, World Bank Group, and the European Investment Bank - were lending to the bank or had an equity participation in it before the crisis.

Finally, we collect information about the development of the ownership structure of each bank over time. Bank-specific and time-varying information on ownership is crucial as the process of foreign bank entry differed considerably across countries in terms of intensity and timing. For the period 1999-2004, ownership information is taken from De Nicolò and Loukoianova (2007). For later years we manually pull information from bank websites and annual reports. For foreign bank subsidiaries we trace back in which year $t$ they became part of a group. For newly established subsidiaries by parent banks, we then use data from year $t$ onwards. For subsidiaries that are the result of a takeover, we only use data from year $t+1$ onwards. In this way we take into account that after a take-over the influence of the new parent bank is not immediate but only noticeable when the integration process is

\footnotetext{
10 Our definition of 'Emerging Europe' comprises Albania, Armenia, Azerbaijan, Belarus, Bosnia and Herzegovina, Bulgaria, Croatia, Czech Republic, Estonia, Georgia, Hungary, Kazakhstan, Kyrgyzstan, Latvia, Lithuania, FYR of Macedonia, Moldova, Mongolia, Montenegro, Poland, Romania, Russia, Serbia, Slovak Republic, Slovenia, Tajikistan, Turkey, Turkmenistan, Ukraine, and Uzbekistan.

11 In particular European Commission memorandum no. 10/284, State aid: Overview of national measures adopted as a response to the financial/economic crisis, Brussels, 29 June 2010.
} 
well under way. If parent banks merge during year $t$ we include the merged entity from $t+1$ onwards for similar reasons.

Our main dependent variable is annual gross nominal credit growth. We define gross nominal credit as net loans plus loan loss reserves. This definition corrects for changes in (net) loans that are not due to changes in banks' output of new loans but are caused by changes in loan loss provisioning and write-offs. ${ }^{12}$ If certain banks provisioned more during the crisis than others, this should therefore not bias our dependent variable. The same holds for state banks that may have provisioned very little and instead 'ever-greened' non-performing loans. To exclude observations related to mergers and acquisitions we trim the one per cent observations with the highest loan growth.

Table 1 summarizes the development of credit growth across Emerging Europe. After abundant annual growth during 1999-2007 -of on average 50 per cent- lending slowed markedly in 2008 and further in 2009. Before the crisis, credit growth was somewhat higher among foreign banks and this difference was most pronounced in south-eastern Europe (SEE). Foreign bank subsidiaries typically had easier access to foreign funding -either from international capital markets or from their parent banks (De Haas and Naaborg, 2006)- and were less constrained by the availability of local funding.

During the crisis, both foreign and domestic banks had to cut credit growth significantly. In SEE, foreign banks reduced credit growth relatively fast in 2008 when compared to their very high precrisis rates of expansion. In absolute terms, credit growth of domestic and foreign banks in Central and Eastern Europe \& the Baltic States (CEB) and SEE converged in 2008 and 2009.

\section{[Insert Table 1 here]}

In the Commonwealth of Independent States (CIS), Russia, and Turkey foreign banks did relatively well during the crisis as domestic banks decelerated at a fast pace. Kazakh, Russian, and Ukrainian domestic banks had leveraged themselves with large amounts of foreign debt that they now found difficult to roll over. Note that lending by state banks held up quite well in 2009 in the CIS and SEE. ${ }^{13}$ When we compare those foreign banks in CEB and SEE that became part of the VI in 2009 with those that did not, it becomes clear that the former were among the fastest growing banks in Emerging Europe before the crisis (this difference is statistically significant at the 1 per cent level). During the crisis, both types of foreign banks slowed down their lending and in 2009 credit even contracted for VI banks in CEB.

\footnotetext{
${ }^{12}$ Our results continue to hold when we use net loans as our dependent variable (see Table 4).

${ }^{13}$ For instance, VTB - Russia's second largest (and state-owned) bank - grew by 53 per cent in 2009 while Gazprombank, another large Russian state bank, increased credit by 38 per cent. In south-eastern Europe, Bulgarian Municipal Bank grew by 13 per cent and Slovenian Banka Celje by 11 per cent during 2009.
} 
In sum, Table 1 indicates that in CEB and SEE foreign banks grew faster than domestic banks before the crisis. During the crisis, both types of banks displayed low but similar growth rates, implying that foreign banks had to decelerate more. Further east, foreign and domestic banks had been growing at similar rates before the crisis, but domestic banks had to cut lending more once the crisis struck.

Tables A1-A3 in the Annex provide variable definitions, descriptive statistics, and a correlation matrix. 29 per cent of the banks in our sample are foreign owned, 63 per cent domestic private banks, and 8 per cent state-owned banks. About 4 per cent of all banks received some form of government support (excluding the VI) during the crisis years 2008-09. Banks' loan-to-deposit ratio, an indicator of their use of wholesale funding, was on average 91.4 per cent. However, variation is large with some banks operating at considerably higher ratios, in particular at the height of the pre-crisis credit boom. Loan quality varies significantly, with the ratio of loan loss reserves to gross loans lower among foreign banks (4.5 per cent) and higher among state banks (6.8).

Tables A4 and A5 in the Annex provide an overview of the banks that participated in the VI and the specific countries in which they signed commitment letters. Importantly, in each of the five VI countries there were two groups of foreign bank subsidiaries: those with parents that were part of the VI in that country and those with parent banks that were not. For instance, in Hungary UniCredit and Raiffeisen Bank signed a commitment letter whereas Commerzbank and Deutsche Bank did not.

The table also shows variation among foreign bank subsidiaries according to whether their parent banks received government support or not. For instance, Commerzbank received capital support from the German government whereas Deutsche Bank did not. Moreover, note that parent banks signed commitment letters in some countries but not in others. Erste Bank signed a letter in Hungary but not in Serbia. Similarly, NLB Bank committed to rollovers in Bosnia \& Herzegovina but not in Serbia. These are the sources of between-bank and within-bank variation that we exploit in this paper.

The decision of a parent bank to participate in the VI and to sign commitment letters in specific countries was not random. Table A6 provides a probit analysis to analyze what determined a bank's VI status. We assess the impact of both parent bank and subsidiary characteristics. The results indicate that large banks - in terms of both the asset size of the subsidiary and the regional exposure of the parent bank (number of subsidiaries in Emerging Europe) - were more likely to be part of the VI. Parents of subsidiaries with relatively low loan-quality (high loan-loss reserves) were also more likely to sign commitment letters as were parent banks with lower tier 1 capital ratios.

These results indicate that while VI banks were on average larger, they were also less well capitalized, and carried more non-performing loans. These selection effects therefore stack against us finding a positive impact of the VI on credit growth during the crisis. They also indicate that it is important to control for bank characteristics in order to minimize the risk of omitted-variables bias. 


\section{Empirical methodology}

We start our empirical analysis by reporting a set of panel regressions for the period 1999-2009 to analyze whether foreign bank subsidiaries continued to be relatively stable providers of credit, as they had been during earlier local crises, or whether they were more fickle during the recent crisis. In each specification we include time-varying bank-ownership dummies $-O W N_{i j t}$ - to distinguish between domestic private banks (the control group), state banks, and foreign banks. ${ }^{14}$

In addition, we construct five time-invariant Vienna participation dummy variables. The first one, $V_{I E N N A}$ COUNTRY ${ }_{j}$ indicates whether a country was one of the five VI countries or not. Second, VIENNA $\operatorname{PARENT}_{i j}$, specifies whether the parent bank of subsidiary $i$ in country $j$ signed one or more VI commitment letters (in country $j$ or elsewhere). Third, VIENNA LETTER $i j$ indicates whether the parent bank of subsidiary $i$ in country $j$ signed a VI commitment letter in country $j$. Fourth, PARENT SIGNED ELSEWHERE $_{i j}$ indicates whether the parent bank of subsidiary $i$ in country $j$ signed a VI commitment letter but not in country $j$. Fifth, NON-VIENNA PARENT $i j$ indicates whether the parent bank of subsidiary $i$ in country $j$ did not sign any VI commitment letters. Finally, we also create $S_{U P P O R T}$, a dummy variable that identifies whether the parent bank of subsidiary $i$ in country $j$ received some form of home-country government support.

Our priors about the impact of government support versus VI participation on credit growth differ. In the case of traditional government support, we expect a negative relationship to the extent that support came with 'protectionist' strings attached. Only if government support had a strong positive impact on banks' financial positions this may have outweighed the impact of a shift towards home-country lending. In the case of VI participation (and the related IFI support) we expect the impact to be positive as this intervention was explicitly targeted at maintaining exposures abroad. To the extent that we adequately control for confounding factors, we expect that banks that signed commitment letters in specific countries in return for financial support, were relatively stable credit sources compared to other foreign banks.

We create two crisis dummies - CRISIS - that are ' 1 ' in either 2008 or 2009 and interact these with the ownership and Vienna variables to analyze whether, all else equal, banks with different ownership structures and VI participation status behaved differently during the crisis.

All panel regressions contain on the right-hand side a matrix of bank-specific, time-varying control variables $-X_{i j t}$ - that measure financial characteristics of the banks as well as macroeconomic conditions in the host country. Because both government support and VI participation were not randomly allocated over the banking population, as discussed in the previous section, it is important to

\footnotetext{
${ }^{14} \mathrm{We}$ also tried specifications where we split up foreign banks into de novo greenfield subsidiaries, established by the parent bank from scratch, and subsidiaries that are the result of a take-over. We did not find any significant differences in the lending behaviour of both types of banks and we therefore do not distinguish between them in our empirical analysis.
} 
control for such bank characteristics. Our dataset allows us to do so, reducing concerns about omitted variable bias. Because government support and VI participation only partially overlapped, and because government support was mainly extended in 2008 and VI participation only in 2009, we can further disentangle the impact of these two types of government intervention.

To the extent that host country inflation increases the nominal value of loan portfolios there would be a positive effect of inflation on credit growth. However, as we convert our data to US dollars, inflationary effects should disappear to the extent that PPP holds. Since inflation differences are usually not immediately and fully offset by adjustments in the nominal exchange rate, we include the inflation rate as a regressor to ensure that we adequately correct for inflation-fuelled growth in nominal loan portfolios. ${ }^{15}$

Summarizing, our baseline panel-regression specification looks as follows:

$$
\Delta L_{i j t}=\alpha_{1}+\gamma_{1} \text { Own }_{i j t}+\gamma_{2} \text { Own }_{i j t} \cdot \text { Crisis }_{t}+\gamma_{3} \text { Vienna }_{i j} \cdot \text { Crisis }_{t}+\gamma_{4} \cdot X_{i j t}+\mu_{t}+\eta_{i j}+\varepsilon_{i j t}
$$

where

- $\Delta L_{i j t}$ is the percentage gross credit growth of bank $i$ in country $j$ in year $t$;

- $\quad \alpha_{l}$ is an intercept term and $\gamma$ are coefficients or coefficient vectors;

- $O W N_{i j t}$ is a matrix of dummy variables that distinguish between domestic private banks (control group), state banks, and foreign banks in country $j$;

- VIENNA $A_{i j}$ is a matrix of dummy variables that indicate banks' status as regards VI participation and government support;

- $\operatorname{CRISIS}_{t}$ is a dummy variable that identifies the 2008 or 2009 crisis year.

- $X_{i j t}$ is a matrix of host country macroeconomic variables, characteristics related to the parent bank of subsidiary banks $i$; as well as of characteristics of the bank $i$ itself;

- $\quad \eta_{i j}$ are bank fixed effects; $\mu_{t}$ year fixed effects, and $\varepsilon_{\mathrm{ijt}}$ is the idiosyncratic error, $\varepsilon_{\mathrm{ijt}} \sim \operatorname{IID}\left(0, \sigma_{\varepsilon}^{2}\right)$;

- $\quad i=1, \ldots, N$ where $N$ is the number of bank subsidiaries in the sample;

- $j=1, \ldots, N$ where $N$ is the number of countries in the sample;

- $t=1, \ldots, T_{i}$ where $T_{i}$ is the number of years in the sample for bank subsidiary $i$.

\footnotetext{
${ }^{15}$ If within a country, foreign and domestic banks denominate different proportions of their credit portfolio in foreign currency (FX) versus local currency, then this could confound our results. However, Brown and De Haas (2012), using data from the Banking Environment and Performance Survey (BEPS), show that the proportion of FX lending is in many cases not strongly correlated with ownership structure. For instance, in Bulgaria foreign (domestic) banks provided on average 35 (34) per cent of their 2004 lending in FX. In Latvia these numbers were 63 and 64 and in Estonia 52 and 77.
} 
We estimate this specification using OLS with bank-specific fixed effects (Hausman tests indicate that the bank individual effects are significantly correlated with the explanatory variables) and robust estimators to correct for heteroscedasticity. We include year fixed effects to control for global trends that influenced all banks simultaneously.

Second, we run a set of cross-section regressions where the dependent variable is bank-specific credit growth in 2009 to analyze the impact of the Vienna Initiative in more detail. We now limit the sample to the five countries that participated in the VI and focus on foreign bank subsidiaries only. Since each of these countries contain several subsidiaries, we can include country fixed effects to rigorously control for credit demand at the country level. ${ }^{16}$ This is important because the crisis hit the real economy of countries to a different extent and with a different lag. Firms' credit demand to finance working capital and investments was consequently affected to varying degrees. This allows us to compare, within the same country, how lending by banks that signed a commitment letter differed from banks that did not sign a letter. This cross-sectional specification looks as follows:

$$
\Delta L_{i j}=\alpha_{1}+\gamma_{1} \cdot \Delta L_{i j, 204-07}+\gamma_{2} \cdot V I_{i j}+\gamma_{3} \cdot X_{i j, 2007}+\eta_{j}+\varepsilon_{i j}
$$

where

- $\quad \Delta L_{i j}$ is the percentage gross credit growth of bank $i$ in country $j$ in 2009;

- $\quad \alpha_{l}$ is an intercept term and $\gamma$ are coefficients or coefficient vectors;

- $\Delta L_{i j, 2005-07}$ is the average annual percentage gross credit growth of bank $i$ in country $j$ during the period 2005-07;

- $\quad V I_{i j}$ is a dummy that indicates whether the parent bank of subsidiary $i$ signed a commitment letter in country $j$;

- $X_{i j t}$ is a matrix of pre-crisis (2007) control variables for the (parent bank of) subsidiary $i$;

- $\eta_{\mathrm{j}}$ are country fixed effects and $\varepsilon_{\mathrm{ij}}$ is the idiosyncratic error, $\varepsilon_{\mathrm{ij}} \sim \operatorname{IID}\left(0, \sigma_{\varepsilon}^{2}\right)$;

\section{Empirical results}

Table 2 shows panel regressions to analyze the relationship between bank-ownership structure and credit growth before and during the crisis. ${ }^{17}$ We explain about 30 per cent of the variation in banks' annual credit growth rates. The top panel shows that before the crisis, foreign banks grew significantly faster than domestic banks, exceeding their annual rate of growth by as much as 20 percentage points. This holds even when controlling for a battery of other (lagged) bank characteristics. In line with our

\footnotetext{
${ }^{16}$ Cetorelli and Goldberg (2011) follow a similar approach on the basis of country-level data on lending from 17 developed countries to 94 emerging markets.

${ }^{17}$ Column (1b) replicates column (1a) while including year fixed effects.
} 
expectations, these controls show that large banks, banks with an already high loan-to-deposit ratio, and banks with high loan loss reserves (i.e. worse loan quality) grew slower on average. More solvent, liquid, and profitable banks expanded credit more quickly. As expected, credit growth was positively correlated with the business cycle - a proxy for credit demand at the host-country level.

\section{[Insert Table 2 here]}

During 2008, foreign banks were the first to sharply curb their credit growth (column 4) and this brought them back in line with the average growth rate of private domestic banks (column 1). ${ }^{18}$ Domestic bank lending slowed mainly in 2009, when the temporary decoupling of emerging markets from economic trends in the developed world came to an end. Interestingly, while state banks also had to slow down credit in 2009 (column 3), this reversal was less sharp when compared to private banks (column 1). This may reflect that in some countries governments used state-owned banks to smooth aggregate lending when privately owned banks started to deleverage.

Next, in Table 3 we start to investigate whether the Vienna Initiative had a stabilizing impact on foreign bank lending during the crisis. Using the same panel data as in Table 2, we explore how lending during the crisis differed between banks and countries inside and outside the Vienna Initiative. To keep the table concise, we only report the interaction terms between the crisis years and the VI variables. However, all specifications include the separate components of these interaction terms, time-varying bank controls (the same as in Table 2), as well as bank and year fixed effects. In the last three columns we also include parent-bank characteristics as controls. The first (last) three columns shows regression estimates based on the whole sample (foreign-bank sample).

\section{[Insert Table 3 here]}

The interaction term between Crisis 2008 and VI country shows that in 2008, before the VI was initiated, bank lending dropped significantly more in (future) VI countries compared to non-VI countries. On average, the adjustment in credit growth was about 14 percentage points sharper in the five countries that would need to be supported by the IMF and EU later on. A similar interaction term for 2009 shows how a year later - when the credit crunch intensified on average - VI countries had 'normalized' and the credit decline had become more in line with other countries in the region. We now no longer observe significant differences between VI and non-VI countries in terms of average

\footnotetext{
${ }^{18}$ The sum of the coefficient for Foreign bank and Crisis 2008*Foreign bank is just above or below zero (depending on the inclusion of year fixed effects). Also note that unreported regressions indicate that government support did not have an independent effect on foreign bank lending (see also Tables 4 and 5).
} 
lending contractions. It appears that the stabilization efforts by the IMF and IFIs in 2009, in response to the particularly weak performance of these countries in 2008, at least ensured that credit dynamics became in line with those observed elsewhere in Emerging Europe.

We can now also interact both crisis dummies with Vienna parent to check whether VI banks behaved differently during the crisis, both before (2008) and during the VI (2009). We find that this was indeed the case. Column 1 shows that compared to all other banks, banks that would end up signing VI commitment letters in 2009 saw a relatively sharp decline in credit growth in 2008 (an additional 9 percentage points). This links back to our earlier observation that VI participants were the banks that had been growing the fastest before the crisis (and were larger as a result) but were also less well capitalized and had a weaker loan portfolio.

Interestingly, however, in 2009 these banks had stabilized and there is even statistically weak evidence that they now decelerated less when compared to domestic banks and non-VI foreign banks (column 1). To look into this in more detail, column 3 compares VI foreign banks with non-VI foreign banks while leaving out all observations on domestic banks. The picture is similar: compared to nonVI foreign banks, credit growth of foreign banks that were part of the VI was about 10 percentage points higher (all else equal).

In columns $2 \mathrm{a}, \mathrm{b}$ and $4 \mathrm{a}, \mathrm{b}$ we use the same bank samples but distinguish more finely between different types of VI participation. Because Vienna country is highly correlated with Vienna letter, we show both a specification that includes interaction terms with Vienna country (columns 2a and 4a) and one without those terms (columns $2 \mathrm{~b}$ and $4 \mathrm{~b}$ ). The results indicate that in countries where parent banks eventually signed a commitment letter, foreign bank subsidiaries did worse in 2008. The drop in their credit growth was more than 20 percentage points larger compared to all other banks (column $2 \mathrm{~b}$ ) and about 13 percentage points when compared to other foreign banks (column 4b). However, this was no longer the case in 2009, which confirms our earlier results.

Moreover, columns 2 and 4 indicate that when a parent bank did not sign a commitment letter in a particular country but did do so in another country, we do not find any negative impact on lending in the non-signing country in 2009. It is therefore unlikely that VI banks propped up their lending in VI countries, as per the signed commitment letters, by reducing their lending elsewhere in Emerging Europe. If anything, we find a positive spillover effect: lending by foreign bank subsidiaries whose parent banks signed commitment letters in one or more other countries, was relatively stable. Their credit growth in 2009, compared to the pre-crisis period, exceeds that of all other banks by 7 percentage points (columns 2a,b) and that of other foreign banks by more than 12 percentage points (columns 4a,b).

Finally, the results at the bottom of columns 2a,b suggest that also subsidiaries of parent banks that were not part of the VI in any country, did not do worse in 2009 when compared to domestic banks. 
This confirms the general picture that emerged from Table 2: overall foreign banks had to curb their lending somewhat earlier, already in 2008, but displayed about the same lending behavior in 2009 . Also not that, in line with Table 2, state banks were a relatively stable source of credit during 2009.

Table 4 provides a number of robustness tests on column 3 of Table 3, which we reproduce in column 1 here. In the second column we only include banks for which we have at least seven years of subsequent observations to make sure our results are not driven by banks with just a few data points. Our results on the stabilizing effect of Vienna participation and of state ownership in 2009 continue to hold. In the next column we report estimates with panel-corrected standard errors (PCSE, cf. Beck and Katz, 1995) which allows us to correct for bank-level heteroscedasticity and an AR(1) process in the error structure. Again, our results do not change materially. In column 4 and 5, we show the same specification using a Arellano-Bond (1991) GMM estimator and a Hausman and Taylor (1981) instrumental variable estimator, respectively. Here our results hold as well.

\section{[Insert Table 4 here]}

In column 6 and 7 we replace gross loan growth with net loan growth (i.e. we adjust for provisioning) and growth in total assets, respectively. In the first case, our results continue to hold. In the second case, we find that the positive effect of a parent bank that signed in another country disappears. This may indicate that the Vienna Initiative - and in particular the Joint IFI Action Plan that supported banks' ability to continue lending to firms and households - may have pushed participating banks to continue lending while taking compensating measures to shorten their balance sheet in other ways. Finally, column 8 includes a government support dummy. Our results continue to hold although the state support dummy itself is highly insignificant.

Next, Table 5 reports cross-sectional regressions for 2009 on a sample of foreign bank subsidiaries in the five VI countries: Bosnia and Herzegovina, Hungary, Latvia, Romania, and Serbia. We include host-country fixed effects to control for local demand conditions. This allows us to compare, within the same host country, subsidiaries of banks that signed a commitment letter in that country versus those that did not (whilst controlling for parent bank and subsidiary covariates). Columns 1-3 show regressions with credit growth on the left-hand side and columns 4-6 with asset growth.

\section{[Insert Table 5 here]}

We find among foreign banks in VI countries a clear positive relationship between signing commitment letters on total credit and asset growth in 2009. As in the panel regressions, we do not 
find a separate impact of government support on credit and asset growth. In contrast, even when we control for various parent bank and subsidiary characteristics, including average pre-crisis growth rates, we continue to find a strong and substantial effect of parent banks' commitment letters on subsidiary lending. Finally, the control variables show that, as expected, bank lending was lower for large subsidiaries, subsidiaries with weaker balance sheets (as indicated by higher proportions of loan loss reserves), and subsidiaries that grew faster before the outbreak of the crisis.

\section{Conclusions}

We use a comprehensive dataset with detailed information on 1,294 banks in Emerging Europe to analyze the determinants of credit growth during the 2008-09 crisis. We focus on the impact of bankownership structure and access to government support, either through capital injections by homecountry authorities or through participation in the Vienna Initiative.

We find that foreign bank subsidiaries reduced their lending somewhat earlier, already in 2008, and this brought their pace of lending back in line with that of their domestic peers. While we find no significant impact of home-country government support on foreign bank lending, we do show that foreign banks that took part in the Vienna Initiative appear to be more stable lenders than banks that did not participate. In particular, cross-sectional regressions for the crisis year 2009 indicate that subsidiaries of parent banks that signed commitment letters where significantly more stable sources of credit than subsidiaries of banks that did not sign such letters in the same country. We find no evidence of VI banks withdrawing from non-VI countries in order to maintain exposures to countries where they signed commitment letters. If anything, participation in the VI had positive rather than negative spillover effects to the rest of Emerging Europe. Finally, we show how by the second year of the crisis, state-owned domestic banks had become a relatively stable credit source.

In all, we conclude that the Vienna Initiative, an ad hoc coordination mechanism, was a relatively successful example of catalytic funding where public funds provided by the IMF, EU, and various development institutions where complemented by a coordinated (but non-coercive) bail-in of privatesector lenders. This not only helped countries to close their external funding gaps at the macroeconomic level but also, as we show in this paper, to soften the inevitable deleveraging process in Emerging Europe and to prevent a uncoordinated 'rush to the exit'.

During earlier crises that originated in Emerging Europe itself, parent banks proved to be a source of strength and their subsidiaries actively stabilized local lending. In this paper, we show that during the recent crisis, when parent banks were hit by severe funding shocks at home, foreign bank subsidiaries had to rein in credit growth relatively fast when compared to their high pre-crisis growth rates (bringing credit dynamics in line with those of domestic banks). Because subsidiaries are financially integrated into a group structure, their lending reacts to developments in other parts of the group and 
when parent banks are hit by a funding shock, this may translate into a reduction in lending by their foreign subsidiaries. One implication of these intra-bank financial linkages is that (national) supervisory authorities need to coordinate their policies and supervisory activities across borders. Coordination mechanisms that were set-up before the crisis have proven insufficient and ineffective in the strongly integrated banking markets of Emerging Europe. This resulted in the need to set up an ad hoc coordination mechanism during the crisis, the Vienna Initiative.

Unfortunately, regulatory reform and cooperation in the wake of the 2008-09 crisis has only proceed very slowly. As a result, when in 2011 Western European banks experienced significant funding constraints and were once more under pressure to deleverage, and even to sell local subsidiaries, the need was felt for a "Vienna 2.0". While this new effort will focus again on the short-term task of preventing an uncoordinated and excessive decline in bank lending in the region, the focus will also be on moving the cross-border banking model of Emerging Europe in the direction of a new banking model that relies more on local sources of funding.

Better coordination, cooperation, and information-exchange between supervisors are not only necessary to prevent spillovers of financial shocks, but also because the alternative -forcing highly integrated pan-European banking groups to hold more capital and liquidity in each individual subsidiary- may be costly. 'Ring-fenced' subsidiaries are first of all costly to the bank groups themselves, because the sum of ring-fenced pools of capital will be larger than the current group capital as banks can no longer exploit the benefits of international diversification. ${ }^{19}$ At the macroeconomic level, there may be costs involved too because ring-fenced subsidiaries would impede the efficient functioning of banks' internal capital markets. The ability of multinational banks to raise funding where it is cheapest and allocate it to the most worthy investment projects contributes to a more efficient international allocation of capital.

Ideally, one would like to move towards an integrated supervisory regime that would allow banks to set up multinational networks of branches and subsidiaries through which capital and liquidity can be allocated to its most productive use. At the same time, supervisors should be able to adequately respond to local shocks that hit a banking group and that may have knock-on effects to other parts of the group. At a minimum, such supervisory 'integration' could take the form of more harmonization and a strengthening of the colleges of supervisors on multinational banks, as well as setting up (ex ante and binding) burden-sharing agreements (see for instance Goodhart and Schoenmaker, 2009). A more efficient and effective resolution of cross-border banks in trouble could be tackled by a resolution fund at the EU level or a network of national resolution funds. The most far-reaching solution would entail the creation of a pan-European supervisor for large groups. This could be

\footnotetext{
${ }^{19}$ See Cerutti et al. (2010) for an analysis of the costs for European multinational banks in case of (partial) ringfencing of their subsidiaries in Emerging Europe.
} 
supplemented by adequate capital and liquidity regulation as well as host-country macroprudential supervision able to curb externally funded credit booms.

Whatever policy option will be chosen, forced 'subsidiarisation' through ring-fencing - basically cutting up multinational banks into strings or independent 'local' banks - may be a second-best option that reflects the inability of national supervisors to reach a satisfactory level of cross-border cooperation and burden sharing. Having said that, in particular in Emerging Europe many foreign bank subsidiaries will gradually need to move towards a funding policy that relies more on local and less on parent-bank funding. This requires the development of local capital markets, which will allow banks to 'top up' domestic deposit funding with local wholesale funding if and when required.

\section{References}

Barba Navaretti, G., Calzolari, G., Pozzolo, A. F. and M. Levi (2010), Multinational Banking in Europe: Financial Stability and Regulatory Implications. Lessons from the Financial Crisis, Economic Policy, 25, 703-753.

Beck, N. and J.N. Katz (1995), What to do (and what not to do) with time-series cross-section data, American Political Science Review, 89(3), 634-647.

Brei, M., L. Gambacorta, and G. Von Peter (2011), Rescue packages and bank lending, BIS Working Paper No. 357, Bank for International Settlements, Basel.

Brown, M. and R. De Haas (2012), Foreign banks and foreign currency lending in emerging Europe, Economic Policy, 27(69), 57-98.

Cerutti, E., A. Ilyina, Y. Makarova, and C. Schmieder (2010), Bankers without borders? Implications of ring-fencing for European cross-border banks, IMF Working Paper. No. 10/247, International Monetary Fund, Washington D.C.

Cetorelli, N. and L. Goldberg (2011), Global banks and international shock transmission: Evidence from the crisis, IMF Economic Review, 59(1), 41-76.

Chava, S. and A. Purnanandam (2011), The effect of banking crisis on bank-dependent borrowers, Journal of Financial Economics, 99, 116-135.

Corsetti, G., B. Guimarães, and N. Roubini (2003), International lending of last resort and moral hazard: A model of the IMF's catalytic finance, NBER Working Paper 10125, Cambridge, MA: National Bureau of Economic Research.

Corsetti, G. and N. Roubini (2004), Catalytic IMF finance in emerging economies crises: Theory and empirical evidence, paper prepared for the $10^{\text {th }}$ Dubrovnik Economic Conference. 
Cotarelli, C. and C. Giannini (2002), Bedfellows, hostages, or perfect strangers? Global capital markets and the catalytic effect of IMF crisis lending, IMF Working Paper 02/193, International Monetary Fund, Washington, D.C.

Degryse H., O. Havrylchyk, E. Jurzyk and S. Kozak (2009), Foreign bank entry and credit allocation in emerging markets, IMF Working Paper 09/270, International Monetary Fund, Washington, D.C.

De Haas, R. and I. Naaborg (2006), Foreign banks in transition countries: To whom do they lend and how are they financed?, Financial Markets, Institutions \& Instruments, 15(4), 159-199.

De Haas, R. and N. Van Horen (2012), International shock transmission after the Lehman Brothers collapse: Evidence from syndicated lending, American Economic Review, Papers \& Proceedings, May, forthcoming.

De Haas, R. and I. Van Lelyveld (2006), Foreign banks and credit stability in Central and Eastern Europe. A panel data analysis, Journal of Banking and Finance, 30, 1927-1952.

De Haas, R. and I. Van Lelyveld (2010), Internal capital markets and lending by multinational bank subsidiaries, Journal of Financial Intermediation, 19(1), 1-25.

De Haas, R. and I. Van Lelyveld (2011), Multinational banks and the global financial crisis. Weathering the perfect storm?, EBRD Working Paper No. 135, European Bank for Reconstruction and Development, London.

De Nicolò, G. and E. Loukoianova (2007), Bank Ownership, Market Structure and Risk, IMF Working Paper No. 215, International Monetary Fund, Washington D.C.

Dinger, V. (2011), Do foreign-owned banks affect banking system liquidity risk?, Journal of Comparative Economics, 37, 647-657.

EBRD (2009), Transition Report 2009, London.

Fries, S. and A. Taci (2005), Cost efficiency of banks in transition: Evidence from 289 banks in 15 post-communist countries, Journal of Banking and Finance, 29, 55-81.

Freixas, X (2003), Crisis Management in Europe, In: Financial Supervision in Europe, eds. J.

Kremers, D. Schoenmaker, and P. Wierts, 102-19. Cheltenham: Edward Elgar.

Final report on the joint IFI action plan (2011), EBRD, EIB, World Bank, March $1^{\text {st }}$.

Goodhart, C. and D. Schoenmaker (2009), Fiscal burden sharing in cross-border banking crises, International Journal of Central Banking, 5, 141-165.

Havrylchyk, O. and E. Jurzyk (2011), Inherited or earned? Performance of foreign banks in Central and Eastern Europe, Journal of Banking and Finance, 35(5), 1291-1302.

Kamil, H. and K. Rai (2010), The global credit crunch and foreign banks' lending to EMs: Why did Latin America fare better?, IMF Working Paper 10/102, Washington, D.C. 
Keller, C. (2009), EM Europe: Rollover rates and IMF-EU tensions, Barclays Capital Research Note, July $10^{\text {th }}$.

Levinger, H. (2010), The role of transnational banks in the transmission and resolution of financial crises: The case of Emerging Europe, Thesis Eberhard Karls Universität Tübingen.

Mian, A. (2006), Foreign, private domestic, and government banks: New evidence from emerging markets, mimeo.

Micco, A. and U. Panizza (2006), Bank ownership and lending behavior, Economics Letters, 93, 248254.

Mitra, P., M. Selowsky, and J. Zalduendo (2010), How much adjustment, how much financing?, In: Turmoil at Twenty: Recession, Recovery, and Reform in Central and Eastern Europe and the Former Soviet Union, 75-116, World Bank, Washington, D.C.

Morgan, D., B. Rime and P.E. Strahan (2004), Bank integration and state business volatility, Quarterly Journal of Economics, 119(4), 1555-85.

Morris, S. and H.S. Shin (2006), Catalytic finance: When does it work?, Journal of International Economics, 70(1), 161-177.

Ongena, S., J.-L. Peydró, and N. Van Horen (2012), Shocks abroad, pain at home? Bank-firm level evidence on financial contagion during the recent financial crisis, mimeo.

Peek, J. and E. Rosengren (1997), The international transmission of financial shocks: The case of Japan, American Economic Review, 87, 495-505.

Peek, J. and E. Rosengren (2000), Implications of the globalization of the banking sector: The Latin American experience, New England Economic Review, September/October, 45-63.

Pistor, K. (2011), Governing interdependent financial systems: Lessons from the Vienna Initiative, Columbia Law and Economics Working Paper No. 396, Columbia University School of Law.

Popov, A. and G. Udell (2012), Cross-border banking, credit access, and the financial crisis, Journal of International Economics, forthcoming.

Progress Report on the Joint IFI Action Plan (2009), EBRD, EIB, World Bank, October $5^{\text {th }}$.

Rose, A.K. and T. Wieladek (2011), Financial protectionism: the first tests, External MPV Unit Discussion Paper No. 32, Bank of England, London.

Roubini, N. and B. Setser (2004), Bailouts or Bail-Ins? Responding to Financial Crises in Emerging Economies, Institute for International Economics, Washington, D.C.

Schnabl, P. (2012), Financial globalization and the transmission of bank liquidity shocks: Evidence from an emerging market, Journal of Finance, forthcoming.

World Bank (2009), Global Development Finance. Charting a Global Recovery, Washington D.C. 


\section{Table 1 Credit growth across Emerging Europe}

This table shows the number of bank-year observations, the number of banks, and average annual credit growth by region and by bank ownership before and during the 2008-09 crisis. Growth rates are averaged over banks and weighed by total assets. State banks are more than 30 per cent owned by the state. Domestic private banks are majority owned by domestic private shareholders. Foreign banks are majority foreign owned. Vienna banks are subsidiaries of foreign banks that were part of the Vienna Initiative. CEB is Central Europe and the Baltic States. SEE is south-eastern Europe. CIS is the Commonwealth of Independent States. Source: BankScope

\begin{tabular}{|c|c|c|c|c|c|c|}
\hline \multirow[t]{3}{*}{ Region } & \multirow[t]{3}{*}{ Bank ownership } & \multirow{2}{*}{$\begin{array}{l}\text { No. bank- } \\
\text { year obs. } \\
1999-2009\end{array}$} & \multirow{2}{*}{$\begin{array}{c}\text { No. banks } \\
2009\end{array}$} & \multicolumn{3}{|c|}{ Average annual credit growth } \\
\hline & & & & 1999-2007 & 2008 & 2009 \\
\hline & & (1) & (2) & (3) & (4) & (5) \\
\hline \multirow[t]{6}{*}{ CEB } & Domestic state & 94 & 11 & 0.27 & 0.09 & 0.11 \\
\hline & Domestic private & 497 & 39 & 0.32 & 0.17 & 0.07 \\
\hline & Foreign & 748 & 75 & 0.39 & 0.14 & 0.06 \\
\hline & Vienna & 74 & 8 & 0.45 & 0.13 & -0.05 \\
\hline & Non-Vienna & 674 & 67 & 0.38 & 0.15 & 0.07 \\
\hline & Total & 1,339 & 125 & 0.36 & 0.16 & $\mathbf{0 . 0 7}$ \\
\hline \multirow[t]{6}{*}{ SEE } & Domestic state & 79 & 6 & 0.36 & 0.22 & 0.19 \\
\hline & Domestic private & 340 & 23 & 0.49 & 0.21 & 0.09 \\
\hline & Foreign & 527 & 74 & 0.67 & 0.26 & 0.05 \\
\hline & - Vienna & 165 & 24 & 0.78 & 0.20 & 0.06 \\
\hline & - Non-Vienna & 362 & 50 & 0.63 & 0.28 & 0.05 \\
\hline & Total & 946 & 103 & 0.57 & 0.24 & 0.07 \\
\hline \multirow[t]{4}{*}{ CIS } & Domestic state & 129 & 14 & 0.47 & 0.52 & 0.14 \\
\hline & Domestic private & 675 & 57 & 0.64 & 0.28 & -0.06 \\
\hline & Foreign & 311 & 58 & 0.66 & 0.43 & 0.00 \\
\hline & Total & 1,115 & 129 & 0.62 & 0.36 & -0.01 \\
\hline \multirow[t]{4}{*}{ Russia } & Domestic state & 173 & 38 & 0.53 & 0.50 & 0.06 \\
\hline & Domestic private & 2,463 & 632 & 0.51 & 0.50 & 0.00 \\
\hline & Foreign & 192 & 38 & 0.53 & 0.44 & 0.15 \\
\hline & Total & 2,828 & 708 & 0.51 & 0.50 & 0.01 \\
\hline \multirow[t]{4}{*}{ Turkey } & Domestic state & 25 & 4 & 0.19 & 0.09 & 0.22 \\
\hline & Domestic private & 137 & 17 & 0.44 & -0.05 & 0.13 \\
\hline & Foreign & 89 & 12 & 0.44 & 0.05 & 0.18 \\
\hline & Total & 251 & 33 & 0.41 & 0.00 & 0.16 \\
\hline
\end{tabular}


Table 2 Bank ownership and credit growth during the 2008-09 crisis

This table shows panel regressions to estimate the impact of bank ownership on credit growth before and during the crisis. The dependent variable is yearly credit growth (\%). The sample period is 19992009. All independent variables are defined in Table A1. Crisis 2008 (2009) is a year dummy which is ' 1 ' in 2008 (2009). Robust p-values appear in brackets and ***, **,* correspond to the one, five and ten percent level of significance, respectively.

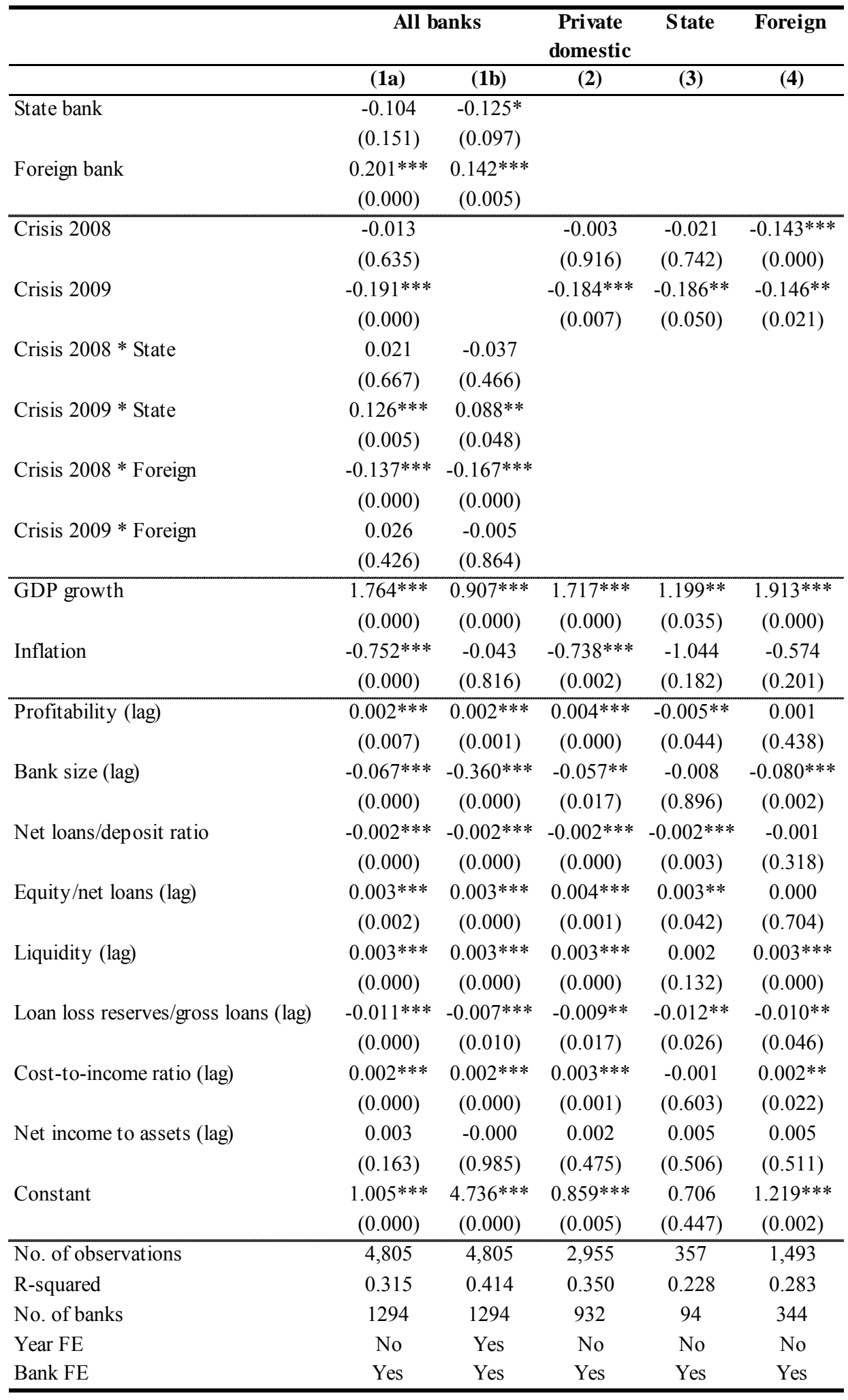


Table 3 The Vienna Initiative and credit growth

This table shows panel regressions to estimate the impact of the Vienna Initiative ('VI') on credit growth. The dependent variable is yearly credit growth (\%). The sample period is 1999-2009. All independent variables are defined in Table A1. Crisis 2008 (2009) is a year dummy which is '1' in 2008 (2009). All regressions include GDP growth, inflation, and the same bank-specific control variables as in Table 2 as (unreported) time-varying control variables. The constant is not shown. Robust p-values appear in brackets and ***,**,* correspond to the one, five and ten percent level of significance, respectively.

\begin{tabular}{|c|c|c|c|c|c|c|}
\hline & \multicolumn{3}{|c|}{ All banks } & \multicolumn{3}{|c|}{ Foreign banks } \\
\hline & (1) & (2a) & (2b) & (3) & (4a) & (4b) \\
\hline Vienna country*2008 & $\begin{array}{c}-0.145^{* * *} \\
(0.000)\end{array}$ & $\begin{array}{c}-0.132 * * * \\
(0.004)\end{array}$ & & $\begin{array}{c}-0.132 * * * \\
(0.010)\end{array}$ & $\begin{array}{l}-0.117 \\
(0.109)\end{array}$ & \\
\hline Vienna country*2009 & $\begin{array}{l}-0.012 \\
(0.771)\end{array}$ & $\begin{array}{c}0.025 \\
(0.598)\end{array}$ & & $\begin{array}{l}-0.095^{*} \\
(0.083)\end{array}$ & $\begin{array}{l}-0.048 \\
(0.553)\end{array}$ & \\
\hline Vienna parent*2008 & $\begin{array}{c}-0.088 * * \\
(0.012)\end{array}$ & & & $\begin{array}{l}-0.008 \\
(0.891)\end{array}$ & & \\
\hline Vienna parent*2009 & $\begin{array}{l}0.052 * \\
(0.009)\end{array}$ & & & $\begin{array}{l}0.102 * \\
(0.055)\end{array}$ & & \\
\hline Vienna letter*2008 & & $\begin{array}{l}-0.106 \\
(0.134)\end{array}$ & $\begin{array}{c}-0.231 * * * \\
(0.000)\end{array}$ & & $\begin{array}{l}-0.030 \\
(0.727)\end{array}$ & $\begin{array}{l}-0.125^{*} \\
(0.083)\end{array}$ \\
\hline Vienna letter*2009 & & $\begin{array}{l}-0.048 \\
-0.501\end{array}$ & $\begin{array}{c}-0.022 \\
(0.698)\end{array}$ & & $\begin{array}{c}0.036 \\
(0.715)\end{array}$ & $\begin{array}{l}-0.002 \\
(0.980)\end{array}$ \\
\hline Parent signed elsewhere*2008 & & $\begin{array}{c}-0.119 * * * \\
(0.002)\end{array}$ & $\begin{array}{c}-0.125 * * * \\
(0.001)\end{array}$ & & $\begin{array}{l}-0.003 \\
(0.956)\end{array}$ & $\begin{array}{c}0.005 \\
(0.932)\end{array}$ \\
\hline Parent signed elsewhere*2009 & & $\begin{array}{l}0.067 * \\
(0.052)\end{array}$ & $\begin{array}{l}0.069 * * \\
(0.047)\end{array}$ & & $\begin{array}{l}0.115 * * \\
(0.036)\end{array}$ & $\begin{array}{l}0.119 * * \\
(0.030)\end{array}$ \\
\hline Non-Vienna parent*2008 & & $\begin{array}{c}-0.121 * * * \\
(0.009)\end{array}$ & $\begin{array}{c}-0.134 * * * \\
(0.003)\end{array}$ & & & \\
\hline Non-Vienna parent*2009 & & $\begin{array}{l}-0.005 \\
(0.890)\end{array}$ & $\begin{array}{l}-0.002 \\
(0.963)\end{array}$ & & & \\
\hline State*2008 & $\begin{array}{l}-0.007 \\
(0.891)\end{array}$ & $\begin{array}{l}-0.030 \\
(0.545)\end{array}$ & $\begin{array}{l}-0.039 \\
(0.437)\end{array}$ & & & \\
\hline State*2009 & $\begin{array}{l}0.092 * * \\
(0.042)\end{array}$ & $\begin{array}{l}0.087 * \\
(0.059)\end{array}$ & $\begin{array}{l}0.087 * \\
(0.061)\end{array}$ & & & \\
\hline No. observations & 4,805 & 4,805 & 4,805 & 1,287 & 1,287 & 1,287 \\
\hline No. banks & 1,294 & 1,294 & 1,294 & 292 & 292 & 292 \\
\hline R-squared & 0.596 & 0.597 & 0.596 & 0.595 & 0.595 & 0.595 \\
\hline Bank controls & Yes & Yes & Yes & Yes & Yes & Yes \\
\hline Parent controls & No & No & No & Yes & Yes & Yes \\
\hline Macroeconomic controls & Yes & Yes & Yes & Yes & Yes & Yes \\
\hline Year FE & Yes & Yes & Yes & Yes & Yes & Yes \\
\hline Bank FE & Yes & Yes & Yes & Yes & Yes & Yes \\
\hline
\end{tabular}




\section{Table 4 Robustness tests}

This table shows robustness tests of column (3) in Table 3 (here repeated in column 1). Column (2) shows a specification which only includes observations where we observe at least seven years of data for a bank. Column (3) shows a specification with panel-corrected standard errors which combine bank-level heteroscedasticity with an AR(1) process. Column (4) shows a specification using the Arellano-Bond GMM estimator. Column (5) shows a specification using the Hausman and Taylor (1981) estimator. Column (6) shows a regression where the dependent variables is net instead of gross loan growth. Column (7) shows a regression where the dependent variable is growth of total assets. Column (8) includes a dummy that is "1" in case a bank received government support in 2008 or 2009. All independent variables are defined in Table A1. Crisis 2008 (2009) is a year dummy which is ' 1 ' in 2008 (2009). All regressions include GDP growth, inflation, and the same bank-specific control variables as in Table 2 as (unreported) time-varying control variables. Country dummy variables and the constant are not shown. Robust p-values appear in brackets and $* * *, * *, *$ correspond to the one, five and ten percent level of significance, respectively.

\begin{tabular}{|c|c|c|c|c|c|c|c|c|}
\hline & Base & $7+$ years & PCSE & GMM & HTaylor & $\begin{array}{c}\text { Loan } \\
\text { growth }\end{array}$ & $\begin{array}{c}\text { Asset } \\
\text { growth }\end{array}$ & Support \\
\hline & (1) & (2) & (3) & (4) & (5) & (6) & (7) & (8) \\
\hline Vienna letter*2008 & $\begin{array}{c}-0.231 * * * \\
(0.000)\end{array}$ & $\begin{array}{l}-0.038 \\
(0.509)\end{array}$ & $\begin{array}{c}-0.308^{* * *} \\
(0.000)\end{array}$ & $\begin{array}{c}-0.344 * * * \\
(0.000)\end{array}$ & $\begin{array}{c}-0.291 * * * \\
(0.000)\end{array}$ & $\begin{array}{c}-0.235^{* * *} \\
(0.000)\end{array}$ & $\begin{array}{c}-0.191 * * * \\
(0.002)\end{array}$ & $\begin{array}{c}-0.215^{* * *} \\
(0.001)\end{array}$ \\
\hline Vienna letter*2009 & $\begin{array}{l}-0.022 \\
(0.698)\end{array}$ & $\begin{array}{l}-0.051 \\
(0.374)\end{array}$ & $\begin{array}{l}-0.068 \\
(0.344)\end{array}$ & $\begin{array}{c}-0.074 \\
(0.285)\end{array}$ & $\begin{array}{l}-0.049 \\
(0.513)\end{array}$ & $\begin{array}{l}-0.033 \\
(0.573)\end{array}$ & $\begin{array}{c}0.031 \\
(0.596)\end{array}$ & $\begin{array}{l}-0.000 \\
(0.998)\end{array}$ \\
\hline Parent signed elsewhere*2008 & $\begin{array}{c}-0.125^{* * *} \\
(0.001)\end{array}$ & $\begin{array}{c}0.050 \\
(0.254)\end{array}$ & $\begin{array}{c}-0.119 * * * \\
(0.004)\end{array}$ & $\begin{array}{c}-0.115^{* * *} \\
(0.009)\end{array}$ & $\begin{array}{l}-0.088 * \\
(0.066)\end{array}$ & $\begin{array}{c}-0.121 * * * \\
(0.002)\end{array}$ & $\begin{array}{c}-0.184 * * * \\
(0.000)\end{array}$ & $\begin{array}{c}-0.108 * * \\
(0.026)\end{array}$ \\
\hline Parent signed elsewhere*2009 & $\begin{array}{c}0.069 * * \\
(0.047)\end{array}$ & $\begin{array}{c}0.073 * * \\
(0.050)\end{array}$ & $\begin{array}{l}0.081 * \\
(0.053)\end{array}$ & $\begin{array}{c}0.096 * * \\
(0.033)\end{array}$ & $\begin{array}{l}0.112 * * \\
(0.024)\end{array}$ & $\begin{array}{l}0.068 * \\
(0.062)\end{array}$ & $\begin{array}{l}-0.001 \\
(0.969)\end{array}$ & $\begin{array}{l}0.089^{*} \\
(0.065)\end{array}$ \\
\hline Non-Vienna parent*2008 & $\begin{array}{c}-0.134 * * * \\
(0.003)\end{array}$ & $\begin{array}{c}0.032 \\
(0.572)\end{array}$ & $\begin{array}{c}-0.099 * * \\
(0.044)\end{array}$ & $\begin{array}{c}-0.118^{* *} \\
(0.016)\end{array}$ & $\begin{array}{c}-0.134 * * * \\
(0.003)\end{array}$ & $\begin{array}{c}-0.137 * * * \\
(0.003)\end{array}$ & $\begin{array}{c}-0.160 * * * \\
(0.000)\end{array}$ & $\begin{array}{c}-0.128 * * * \\
(0.008)\end{array}$ \\
\hline Non-Vienna parent*2009 & $\begin{array}{l}-0.002 \\
(0.963)\end{array}$ & $\begin{array}{c}0.015 \\
(0.719)\end{array}$ & $\begin{array}{l}-0.014 \\
(0.770)\end{array}$ & $\begin{array}{l}-0.012 \\
(0.789)\end{array}$ & $\begin{array}{c}0.005 \\
(0.909)\end{array}$ & $\begin{array}{l}-0.004 \\
(0.922)\end{array}$ & $\begin{array}{c}0.047 \\
(0.178)\end{array}$ & $\begin{array}{c}0.006 \\
(0.887)\end{array}$ \\
\hline State*2008 & $\begin{array}{l}-0.039 \\
(0.437)\end{array}$ & $\begin{array}{c}0.080 \\
(0.223)\end{array}$ & $\begin{array}{c}0.034 \\
(0.509)\end{array}$ & $\begin{array}{l}-0.007 \\
(0.901)\end{array}$ & $\begin{array}{c}0.038 \\
(0.511)\end{array}$ & $\begin{array}{l}-0.035 \\
(0.504)\end{array}$ & $\begin{array}{l}-0.048 \\
(0.402)\end{array}$ & $\begin{array}{l}-0.039 \\
(0.436)\end{array}$ \\
\hline State*2009 & $\begin{array}{l}0.087^{*} \\
(0.061)\end{array}$ & $\begin{array}{c}0.125^{* *} \\
(0.020)\end{array}$ & $\begin{array}{c}0.129 * * \\
(0.018)\end{array}$ & $\begin{array}{c}0.109 * * \\
(0.033)\end{array}$ & $\begin{array}{c}0.144 * * \\
(0.012)\end{array}$ & $\begin{array}{c}0.095 * * \\
(0.048)\end{array}$ & $\begin{array}{c}0.112^{* *} \\
(0.026)\end{array}$ & $\begin{array}{l}0.086^{*} \\
(0.062)\end{array}$ \\
\hline Support 2008/2009 & & & & & & & & $\begin{array}{l}-0.025 \\
(0.542)\end{array}$ \\
\hline No. observations & 4,805 & 2,571 & 4,805 & 4,805 & 4,805 & 4,805 & 4,805 & 4,805 \\
\hline No. banks & 1,294 & 346 & 1,294 & 1,294 & 1,294 & 1,294 & 1,294 & 1,294 \\
\hline R-squared & 0.596 & 0.475 & 0.281 & - & - & 0.597 & 0.608 & 0.596 \\
\hline Bank controls & Yes & Yes & Yes & Yes & Yes & Yes & Yes & Yes \\
\hline Parent controls & No & No & No & No & No & No & No & No \\
\hline Macroeconomic controls & Yes & Yes & Yes & Yes & Yes & Yes & Yes & Yes \\
\hline Year FE & Yes & Yes & No & No & No & Yes & Yes & Yes \\
\hline Bank FE & Yes & Yes & No & No & No & Yes & Yes & Yes \\
\hline Country FE & No & No & Yes & Yes & Yes & No & No & No \\
\hline
\end{tabular}


Table 5 The Vienna Initiative, commitment letters, and bank lending in 2009

This table shows cross-sectional regressions to estimate the impact of signing VI commitment letters on credit growth. The dependent variables are annual credit and annual assets growth in 2009 (\%). All independent variables are defined in Table A1. All regressions include country fixed effects to control for credit demand. The sample includes foreign bank subsidiaries in the five VI countries Bosnia \& Herzegovina, Hungary, Latvia, Romania, and Serbia. Robust p-values appear in brackets and $* * *, * *, *$ correspond to the one, five and ten percent level of significance, respectively.

\begin{tabular}{|c|c|c|c|c|c|c|}
\hline & \multicolumn{3}{|c|}{ Credit growth } & \multicolumn{3}{|c|}{ Asset growth } \\
\hline & (1) & (2) & (3) & (4) & (5) & (6) \\
\hline \multirow[t]{2}{*}{ Vienna letter } & 0.053 & $0.149 * *$ & $0.180 * *$ & $0.116^{* *}$ & $0.122 *$ & $0.149 * *$ \\
\hline & $(0.259)$ & $(0.038)$ & $(0.016)$ & $(0.011)$ & $(0.061)$ & $(0.030)$ \\
\hline \multirow[t]{2}{*}{ Support } & & -0.138 & -0.140 & & -0.066 & -0.067 \\
\hline & & $(0.194)$ & $(0.185)$ & & $(0.262)$ & $(0.240)$ \\
\hline \multirow[t]{2}{*}{ Pre-crisis average annual credit (asset) growth } & & $0.179 * * *$ & $0.145 * * *$ & & $0.133 * *$ & $0.104^{*}$ \\
\hline & & $(0.000)$ & $(0.005)$ & & $(0.010)$ & $(0.093)$ \\
\hline \multirow[t]{2}{*}{ Bank size (lag) } & & $-0.101 * * *$ & $-0.119 * * *$ & & -0.043 & $-0.058 *$ \\
\hline & & $(0.000)$ & $(0.000)$ & & $(0.161)$ & $(0.087)$ \\
\hline \multirow[t]{2}{*}{ Loan loss reserves/gross loans (lag) } & & -0.012 & -0.013 & & $-0.011 * *$ & $-0.012 * *$ \\
\hline & & $(0.273)$ & $(0.245)$ & & $(0.036)$ & $(0.023)$ \\
\hline \multirow[t]{2}{*}{ Size parent bank (lag) } & & & $0.013 * *$ & & & 0.011 \\
\hline & & & $(0.017)$ & & & $(0.159)$ \\
\hline No. of observations & 54 & 54 & 54 & 54 & 54 & 54 \\
\hline R-squared & 0.17 & 0.43 & 0.46 & 0.36 & 0.49 & 0.52 \\
\hline Country FE & Yes & Yes & Yes & Yes & Yes & Yes \\
\hline Bank FE & No & No & No & No & No & No \\
\hline Bank controls & No & Yes & Yes & No & Yes & Yes \\
\hline Parent FE & No & No & No & No & No & No \\
\hline Parent controls & No & No & Yes & No & No & Yes \\
\hline
\end{tabular}




\section{Table A1 Variable descriptions}

This table presents definitions and sources of all variables used in our empirical analysis. BankScope is Bureau van Dijk's BankScope database. IFS are the International Financial Statistics provided by the International Monetary Fund.

\begin{tabular}{|c|c|c|c|}
\hline Variable name & Periodicity & Description & Source \\
\hline \multicolumn{4}{|c|}{ Bank-level data (\# banks = 1,294) } \\
\hline Private domestic bank & $1999-2009$ & $1=$ bank is privately domestically owned & BankScope, websites \\
\hline State bank & $1999-2009$ & $1=$ bank is $>30$ per cent owned by the state & BankScope, websites \\
\hline Support & $2008-2009$ & $\begin{array}{l}\text { 1= bank received government support (asset sale, capital } \\
\text { injection, and/or guarantee) }\end{array}$ & Websites \\
\hline Vienna parent & 2009 & $\begin{array}{l}1=\text { subsidiary is owned by a parent bank that signed up to } \\
\text { the Vienna Initiative }\end{array}$ & EBRD \\
\hline Non-Vienna parent & 2009 & $\begin{array}{l}1=\text { subsidiary is owned by a parent bank that did not sign } \\
\text { up to the Vienna Initiative }\end{array}$ & EBRD \\
\hline Vienna country & 2009 & $\begin{array}{l}1=\text { subsidiary is based in a country part of the Vienna } \\
\text { Initiative }\end{array}$ & EBRD \\
\hline Vienna letter & 2009 & $\begin{array}{l}1=\text { parent bank signed a commitment letter in the } \\
\text { subsidiary's host country }\end{array}$ & EBRD \\
\hline Parent signed elsewhere & 2009 & $\begin{array}{l}1=\text { parent bank signed a commitment letter in another but } \\
\text { not in the subsidiary's country }\end{array}$ & EBRD \\
\hline Pre-crisis IFI client & 2009 & $\begin{array}{l}1=\text { subsidiary was a client of the EBRD, IFC, or EIB } \\
\text { before } 2008\end{array}$ & EBRD \\
\hline Regional exposure & 2007 & $\begin{array}{l}\text { Number of subsidiaries that a foreign bank owns in } \\
\text { Emerging Europe }\end{array}$ & BankScope \\
\hline Crisis $08(09)$ & $2008-2009$ & $1=$ bank observation in the year 2008 (2009) & - \\
\hline & & Annual percentage growth in gross loans $(=$ net loans plus & \\
\hline Credit growth & $1999-2009$ & loan loss reserves) & BankScope \\
\hline Asset growth & $1999-2009$ & Annual percentage growth in total assets & BankScope \\
\hline Deposit growth & $1999-2009$ & Annual percentage growth in deposits & BankScope \\
\hline Profitability & $1999-2009$ & Return on average equity (in \%) & BankScope \\
\hline Bank size & $1999-2009$ & Log total assets in thousands of US\$ & BankScope \\
\hline Loan/deposit ratio & $1999-2009$ & Net loans/short term funding (in \%) & BankScope \\
\hline Tier 1 & $1999-2009$ & Tier 1 capital ratio & BankScope \\
\hline Solvency & $1999-2009$ & Equity/net loans (in \%) & BankScope \\
\hline Liquidity & $1999-2009$ & Liquid Assets / Dep \& ST Funding (in \%) & BankScope \\
\hline Net interest margin & $1999-2009$ & Net interest income / Earning assets(in \%) & BankScope \\
\hline Efficiency & $1999-2009$ & Cost/income ratio (in \%) & BankScope \\
\hline Loan quality & $1999-2009$ & Loan loss reserves/gross loans (in \%) & BankScope \\
\hline \multicolumn{4}{|c|}{ Country-level data $(\#$ countries $=30)$} \\
\hline GDP per capita & $1999-2009$ & $\begin{array}{l}\text { Lagged log GDP per capita, PPP (constant } 2005 \\
\text { international US\$) }\end{array}$ & IFS \\
\hline GDP growth & $1999-2009$ & Real GDP growth (in \%) & IFS \\
\hline & & Deviation of GDP growth from its period average (in \%) & \\
\hline GDP volatility & $1999-2009$ & & IFS, authors' calculations \\
\hline Inflation & $1999-2009$ & Change in CPI inflation, end of period (in \%) & IFS \\
\hline Inflation volatility & $1999-2009$ & Deviation of inflation from its period average (in \%) & IFS, authors' calculations \\
\hline Exchange rate change & 1999-2009 & Change in local curreny unit/USD period average (in \%) & IFS \\
\hline Exchange rate volatility & 1999-2009 & $\begin{array}{l}\text { Deviation of exchange rate annual change from its period } \\
\text { average (in \%) }\end{array}$ & IFS, authors' calculations \\
\hline
\end{tabular}




\section{Table A2 Descriptive statistics}

This table provides summary statistics for all the bank-level and country-level variables. Table A1 provides variable definitions and sources. Panel A contains summary statistics for the full sample as well as conditional means for sub-samples by bank ownership. Panel B contains summary statistics for the country-level variables.

\begin{tabular}{|c|c|c|c|c|c|c|c|c|c|}
\hline & \multicolumn{5}{|c|}{ Full sample summary statistics } & \multicolumn{4}{|c|}{ Means by bank-ownership } \\
\hline & $\begin{array}{c}\text { Average no. } \\
\text { banks per year }\end{array}$ & Mean & Std. Dev. & Min & Max & $\begin{array}{r}\text { Foreign } \\
\text { Vienna }\end{array}$ & $\begin{array}{c}\text { Foreign } \\
\text { non- }\end{array}$ & $\begin{array}{c}\text { Private } \\
\text { domestic }\end{array}$ & State \\
\hline Private domestic & 411 & 0.63 & 0.5 & 0 & 1 & n.a. & n.a. & n.a. & n.a. \\
\hline State bank & 50 & 0.08 & 0.3 & 0 & 1 & n.a. & n.a. & n.a. & n.a. \\
\hline Support & 647 & 0.04 & 0.2 & 0 & 1 & 0.1 & 0.0 & n.a. & n.a. \\
\hline Credit growth & 647 & 40.10 & 48.8 & -66 & 249 & 40.9 & 43.2 & 39.6 & 36.6 \\
\hline Profitability & 647 & 11.3 & 13.0 & -72 & 67 & 11.1 & 8.5 & 11.9 & 11.2 \\
\hline Bank size & 647 & 12.5 & 1.8 & 9 & 19 & 14.2 & 12.8 & 12.0 & 13.4 \\
\hline Loan/deposit ratio & 647 & 91.4 & 50.6 & 8 & 399 & 78.2 & 82.6 & 96.2 & 93.3 \\
\hline Solvency & 647 & 34.0 & 30.4 & 0 & 294 & 21.6 & 37.8 & 35.5 & 38.7 \\
\hline Liquidity & 647 & 45.9 & 27.5 & 3 & 247 & 35.9 & 44.8 & 48.0 & 50.4 \\
\hline Efficiency & 647 & 66.9 & 22.2 & 4 & 196 & 63.6 & 70.3 & 67.1 & 66.2 \\
\hline Loan quality & 647 & 5.7 & 5.6 & 0 & 48 & 4.5 & 4.4 & 6.2 & 6.8 \\
\hline
\end{tabular}

\begin{tabular}{lccccc}
\hline Panel B. Country-level variables (1999-2009) \\
\hline & Obs & Mean & Std. Dev. & Min & Max \\
GDP growth & 6479 & 4.2 & 6.0 & -18.0 & 30.5 \\
Inflation & 6479 & 10.2 & 10.1 & -8.5 & 293.7 \\
\hline
\end{tabular}

\section{Table A3 Pairwise correlations}

This table provides pairwise correlations for our bank-level and country-level variables. Tables A1 and A2 provide variable definitions and sources.

\begin{tabular}{llccccccccccc}
\hline \multicolumn{1}{l}{ Panel A. Bank-level variables } \\
\hline & {$[1]$} & {$[2]$} & {$[3]$} & {$[4]$} & {$[5]$} & {$[6]$} & {$[7]$} & {$[8]$} & {$[9]$} & {$[10]$} & {$[11]$} \\
{$[1]$} & Private domestic & 1.00 & & & & & & & & & \\
{$[2]$} & State & -0.38 & 1.00 & & & & & & & & \\
{$[3]$} & Credit growth & -0.01 & -0.02 & 1.00 & & & & & & & \\
{$[4]$} & Profitability & 0.07 & 0.00 & 0.13 & 1.00 & & & & & & & \\
{$[5]$} & Bank size & -0.39 & 0.14 & -0.02 & 0.11 & 1.00 & & & & & & \\
{$[6]$} & Loan/deposit ratio & 0.12 & 0.01 & 0.01 & -0.03 & -0.15 & 1.00 & & & & & \\
{$[7]$} & Solvency & 0.06 & 0.04 & -0.11 & -0.11 & -0.33 & -0.06 & 1.00 & & & & \\
{$[8]$} & Liquidity & 0.10 & 0.05 & -0.05 & -0.01 & -0.32 & 0.01 & 0.55 & 1.00 & & & \\
{$[9]$} & Loan quality & 0.11 & 0.06 & -0.23 & -0.17 & -0.10 & -0.03 & 0.25 & 0.12 & 1.00 & \\
{$[10]$} & Efficiency & 0.01 & -0.01 & -0.13 & -0.47 & -0.22 & 0.01 & 0.01 & 0.09 & -0.02 & 1.00 \\
{$[11]$} & Profitability & 0.22 & -0.04 & -0.15 & 0.02 & -0.23 & 0.25 & 0.10 & 0.11 & 0.25 & 0.28 & 1.00 \\
\hline
\end{tabular}

\begin{tabular}{llccccc}
\hline \multicolumn{1}{l}{ Panel B. Country-level variables } & & & & \\
\hline & & {$[1]$} & {$[2]$} & {$[3]$} & {$[4]$} & {$[5]$} \\
{$[1]$} & GDP per capita & 1.00 & & & & \\
{$[2]$} & GDP growth & -0.22 & 1.00 & & & \\
{$[3]$} & Inflation & -0.10 & -0.02 & 1.00 & & \\
{$[4]$} & Inflation volatility & -0.31 & 0.12 & 0.02 & 1.00 & \\
{$[5]$} & Exchange rate change & -0.08 & -0.42 & 0.46 & 0.06 & 1.00 \\
\hline
\end{tabular}


Table A4 Overview of government support to parent banks and participation in the Vienna Initiative

This table provides information on the presence of VI support and/or government support for the parent banks of subsidiaries in countries that were part of the Vienna Initiative. Source: EBRD and banks' websites. "Y" ("N") indicate that the subsidiary's parent bank received (did not receive) government support in 2008-09.

\begin{tabular}{|c|c|c|c|c|c|c|c|c|c|c|}
\hline & BO SNIA-HERZEGO VINA & \multirow{2}{*}{ 咅 } & HUNGARY & \multirow{2}{*}{ 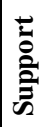 } & LATVIA & \multirow{2}{*}{ 咅 } & ROMANIA & \multirow{2}{*}{ 咅 } & SERBIA & \multirow{2}{*}{ की } \\
\hline & Bank name & & Bank name & & Bank name & & Bank name & & Bank name & \\
\hline \multirow{10}{*}{ 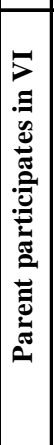 } & Raiffeisen Bank & $\mathrm{Y}$ & UniCredit Bank & Y & DnB Nord Bank & $\mathrm{N}$ & Alpha Bank Romania & $\mathrm{Y}$ & Société Générale Bank Serbia & $\mathrm{Y}$ \\
\hline & Intesa SanPaolo Bank & $\mathrm{Y}$ & Raiffeisen Bank & $\mathrm{Y}$ & SEB Bank & $\mathrm{N}$ & Banc Post & $\mathrm{Y}$ & UniCredit Bank & $\mathrm{Y}$ \\
\hline & UniCredit Bank & $\mathrm{Y}$ & Erste Bank Hungary & $\mathrm{Y}$ & Swedbank & $\mathrm{N}$ & Banca Romaneasca & $\mathrm{Y}$ & Piraeus Bank Beograd & $\mathrm{Y}$ \\
\hline & HypoAlpe-Adria-Bank & $\mathrm{Y}$ & K\&H Bank & $\mathrm{Y}$ & & & Piraeus Bank Romania & $\mathrm{Y}$ & Eurobank EFG & $\mathrm{Y}$ \\
\hline & ZepterKomercBank BanjaLuka & $\mathrm{Y}$ & CIB Bank & $\mathrm{Y}$ & & & Volksbank Romania & $\mathrm{Y}$ & Volksbank Serbia & $\mathrm{Y}$ \\
\hline & Volksbank BH & $\mathrm{Y}$ & \multirow{5}{*}{\multicolumn{2}{|c|}{ Magyar Takarekszövetkezeti Ba Y }} & & & Banca Comerciala Romana & $\mathrm{Y}$ & Alpha Bank Serbia & $\mathrm{Y}$ \\
\hline & NLB Bank & $\mathrm{N}$ & & & & & UniCredit Tiriac Bank & $\mathrm{Y}$ & Vojvodjanska Bank & $\mathrm{Y}$ \\
\hline & & & & & & & BRD - Groupe Societe Generale & $\mathrm{Y}$ & Banca Intesa & $\mathrm{Y}$ \\
\hline & & & & & & & Raiffeisen Bank & $\mathrm{Y}$ & HypoAple-Adria Bank & $\mathrm{Y}$ \\
\hline & & & & & & & & & Raiffeisen Bank & $\mathrm{Y}$ \\
\hline \multirow{9}{*}{ 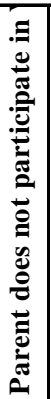 } & Turkish Ziraat Bank Bosnia & $\mathrm{N}$ & KDB Bank & $\mathrm{N}$ & HVB Bank Latvia & $\mathrm{Y}$ & Egnatia Bank & $\mathrm{N}$ & NLB Bank & $\mathrm{N}$ \\
\hline & ProCredit Bank & $\mathrm{N}$ & Volksbank & $\mathrm{Y}$ & & & ProCredit Bank & $\mathrm{N}$ & ProCredit Bank & $\mathrm{N}$ \\
\hline & Bosna Bank International & $\mathrm{N}$ & Commerzbank & $\mathrm{Y}$ & & & ABN Amro Bank & $\mathrm{Y}$ & Erste Bank & $\mathrm{Y}$ \\
\hline & & & Banco Popolare & $\mathrm{Y}$ & & & OTP Bank & $\mathrm{N}$ & OTP Bank & $\mathrm{N}$ \\
\hline & & & Deutsche Bank & $\mathrm{N}$ & & & San Paolo IMI Bank & $\mathrm{Y}$ & Marfin Bank & $\mathrm{N}$ \\
\hline & & & Fundamenta-Lakaskassza & $\mathrm{N}$ & & & Banca de Creditsi Dezvoltare Romexter & $\mathrm{N}$ & Moskovska Bank & $\mathrm{N}$ \\
\hline & & & Allianz Bank & $\mathrm{N}$ & & & Emporiki Bank & $\mathrm{N}$ & Credit Agricole & $\mathrm{Y}$ \\
\hline & & & Budapest Hitel-ésFejleszési Bank & & & & & & Findomestic Bank & $\mathrm{Y}$ \\
\hline & & & & & & & & & KBC Bank & $\mathrm{Y}$ \\
\hline
\end{tabular}


Table A5 Banks participating in the Vienna Initiative and horizontal meetings

This table lists all banks that participated in the horizontal meetings of the Vienna Initative. Source: commitment letters and concluding statements with the IMF and European Commission.

\begin{tabular}{|c|c|c|c|c|c|}
\hline VI country & Commitment letter & Parent banks & Subsidiaries & $\begin{array}{c}\text { Participation } \\
\text { September } 2009\end{array}$ & $\begin{array}{c}\text { Participation } \\
\text { March 2010 Athens }\end{array}$ \\
\hline \multirow{6}{*}{ Hungary } & Signed May 20, 2009 & Bayerische Landesbank & MKB Bank & $\mathrm{x}$ & $\mathrm{x}$ \\
\hline & http://www.imf.org/external/np/cm/2009/052009.htm & Erste Group & Erste Bank Hungary & $\mathrm{x}$ & $\mathrm{x}$ \\
\hline & & Intesa SanPaolo & CIB Bank & $\mathrm{x}$ & $\mathrm{x}$ \\
\hline & & KBC Group & K\&H Bank & $\mathrm{x}$ & $\mathrm{x}$ \\
\hline & & Raiffeisen International & Raiffeisen Bank & $\mathrm{x}$ & $\mathrm{x}$ \\
\hline & & UniCredit Group & UniCredit Bank Hungary & $\mathrm{x}$ & $\mathrm{x}$ \\
\hline \multirow{9}{*}{ Romania } & Signed March 26, 2009 & Erste Group & Banca Comercială Română & $\mathrm{x}$ & $\mathrm{x}$ \\
\hline & Reaffirmed November 18, 2009 & Raiffeisen International & Raiffeisen Bank & $\mathrm{x}$ & $\mathrm{x}$ \\
\hline & http://www.imf.org/external/np/cm/2009/032609.htm & Eurobank EFG & Banc Post & $\mathrm{x}$ & $\mathrm{x}$ \\
\hline & & National Bank of Greece & Banca Romaneasca & $\mathrm{x}$ & $\mathrm{x}$ \\
\hline & & UniCredit Group & UniCredit Tiriac Bank & $\mathrm{x}$ & $\mathrm{x}$ \\
\hline & & Société Générale & $\mathrm{BRD}$ & $\mathrm{x}$ & $\mathrm{x}$ \\
\hline & & Alpha Bank & Alpha Bank Romania & $\mathrm{x}$ & $\mathrm{x}$ \\
\hline & & Volksbank International & Volksbank Romania & $\mathrm{x}$ & $\mathrm{x}$ \\
\hline & & Piraeus Bank & Piraeus Bank Romania & $\mathrm{x}$ & $\mathrm{x}$ \\
\hline \multirow{6}{*}{ Bosnia } & Signed June 22, 2009 & Raiffeisen International & Raiffeisen Bank & $\mathrm{x}$ & $\mathrm{x}$ \\
\hline & http://www.imf.org/external/np/cm/2009/062209.htm & Hypo Alpe-Adria & Hypo Alpe-Adria Bank & $\mathrm{x}$ & $\mathrm{x}$ \\
\hline & & UniCredit Group & UniCredit Bank & $\mathrm{x}$ & $\mathrm{x}$ \\
\hline & & Volksbank International & Volksbank Bosnia & $\mathrm{x}$ & $\mathrm{x}$ \\
\hline & & Intesa SanPaolo & Intesa Sanpaolo Bank & $\mathrm{x}$ & $\mathrm{x}$ \\
\hline & & NLB Group & NLB Bank & & \\
\hline \multirow{10}{*}{ Serbia } & Signed March 272009 & Eurobank EFG & Eurobank EFG & $\mathrm{x}$ & $\mathrm{x}$ \\
\hline & Reaffirmed Feb 262010 & Intesa SanPaolo & Bank Intesa & $\mathrm{x}$ & $\mathrm{x}$ \\
\hline & http://www.imf.org/external/np/cm/2009/032709.htm & Raiffeisen International & Raiffeisen Bank & $\mathrm{x}$ & $\mathrm{x}$ \\
\hline & & Hypo Alpe-Adria & Hypo Alpe-Adria Bank & & $\mathrm{x}$ \\
\hline & & National Bank of Greece & Vojvodjanska Bank & $\mathrm{x}$ & $\mathrm{x}$ \\
\hline & & UniCredit Group & UniCredit Bank Serbia & $\mathrm{x}$ & $\mathrm{x}$ \\
\hline & & Société Générale & Société Générale Bank & $\mathrm{x}$ & $\mathrm{x}$ \\
\hline & & Alpha Bank & Alpha Bank Beograd & $\mathrm{x}$ & $\mathrm{x}$ \\
\hline & & Volksbank International & Volksbank Beograd & $\mathrm{x}$ & $\mathrm{x}$ \\
\hline & & Piraeus Bank & Piraeus Bank Beograd & $\mathrm{x}$ & $\mathrm{x}$ \\
\hline \multirow{4}{*}{ Latvia } & Signed September 11,2009 & Bank DnB NORD & AS DnB NORD Bank & $\mathrm{x}$ & $\mathrm{x}$ \\
\hline & http://www.imf.org/external/np/country/2009/091409.1 & Nordea Bank & Nordea branch & $\mathrm{x}$ & $\mathrm{x}$ \\
\hline & & Swedbank & Swedbank, Latvia & $\mathrm{x}$ & $\mathrm{x}$ \\
\hline & & SEB & SEB Bank Latvia & & $\mathrm{x}$ \\
\hline \multirow{2}{*}{ Other banks } & & ING Bank & & & $\mathrm{x}$ \\
\hline & & OTP Bank & & & $\mathrm{x}$ \\
\hline
\end{tabular}




\section{Table A6 Selection into the Vienna Initiative}

This table shows probit regressions to estimate the likelihood of participation in the Vienna Initiative. Column (1) estimates, at the subsidiary level, the probability that the parent bank of subsidiary $i$ signed a commitment letter in country $j$. Column (2) estimates, at the subsidiary level, the probability that the parent bank of subsidiary $i$ signed a commitment letter in at least one VI country. Column (3) estimates, at the parent-bank level, the probability that a parent bank signed a commitment letter in at least one VI country. All independent variables are defined in Table A1. Robust pvalues appear in brackets and $* * *, * *, *$ correspond to the one, five and ten percent level of significance, respectively.

\begin{tabular}{|c|c|c|c|}
\hline & Vienna letter & Vienna parent & Vienna parent \\
\hline & (1) & $(2)$ & (3) \\
\hline \multirow[t]{2}{*}{ Credit growth 2004-07 } & -0.022 & -0.003 & 0.801 \\
\hline & $(0.362)$ & $(0.907)$ & $(0.473)$ \\
\hline \multirow[t]{2}{*}{ GDP growth country $j$} & -3.271 & $-8.175 * *$ & \\
\hline & $(0.264)$ & $(0.014)$ & \\
\hline \multirow[t]{2}{*}{ Inflation country $j$} & -3.668 & $-8.872 * *$ & \\
\hline & $(0.248)$ & $(0.019)$ & \\
\hline \multirow[t]{2}{*}{ Profitability subsidiary } & 0.009 & 0.012 & \\
\hline & $(0.242)$ & $(0.126)$ & \\
\hline \multirow[t]{2}{*}{ Size subsidiary } & $0.218 * *$ & $0.446 * * *$ & \\
\hline & $(0.032)$ & $(0.000)$ & \\
\hline \multirow[t]{2}{*}{ Loan/dep osit ratio subsidiary } & 0.001 & 0.002 & \\
\hline & $(0.690)$ & $(0.249)$ & \\
\hline \multirow[t]{2}{*}{ Loan quality subsidiary } & $0.082 * *$ & $0.088 * *$ & \\
\hline & $(0.030)$ & $(0.026)$ & \\
\hline \multirow[t]{2}{*}{ Profitability parent bank } & -0.061 & 0.141 & -0.100 \\
\hline & $(0.620)$ & $(0.322)$ & $(0.703)$ \\
\hline \multirow[t]{2}{*}{ Size parent bank } & 0.051 & $0.245 * *$ & 0.076 \\
\hline & $(0.543)$ & $(0.024)$ & $(0.607)$ \\
\hline \multirow[t]{2}{*}{ Loan/deposit ratio parent bank } & 0.005 & $0.008 *$ & 0.006 \\
\hline & $(0.151)$ & $(0.052)$ & $(0.357)$ \\
\hline \multirow[t]{2}{*}{ Tier 1 capital ratio parent } & $-0.000 *$ & $-0.000 * * *$ & $-0.000 *$ \\
\hline & $(0.063)$ & $(0.000)$ & $(0.060)$ \\
\hline \multirow[t]{2}{*}{ Loan quality parent bank } & -0.162 & -0.127 & $-0.471^{*}$ \\
\hline & $(0.185)$ & $(0.278)$ & $(0.055)$ \\
\hline \multirow[t]{2}{*}{ Pre-crisis IFI client } & $0.462 *$ & -0.185 & 0.434 \\
\hline & $(0.074)$ & $(0.583)$ & $(0.573)$ \\
\hline \multirow[t]{2}{*}{ Regional exposure } & $0.066^{*}$ & $0.347 * * *$ & $0.672 * * *$ \\
\hline & $(0.055)$ & $(0.000)$ & $(0.001)$ \\
\hline \multirow[t]{2}{*}{ Constant } & $-6.090 * * *$ & $-13.232 * * *$ & -3.814 \\
\hline & $(0.002)$ & $(0.000)$ & $(0.174)$ \\
\hline No. of observations & 235 & 235 & 66 \\
\hline
\end{tabular}




\section{Table A7 A timeline of the Vienna Initiative}

October $\mathbf{2 6}^{\text {th }} \mathbf{2 0 0 8}$ - IMF approves US\$16.5 billion Stand-By Agreement for Ukraine.

November 6 $^{\text {th }} \mathbf{2 0 0 8}$ - IMF approves $€ 12.3$ billion Stand-By Arrangement for Hungary.

November $27^{\text {th }} 2008$ - Six bank groups (Raiffeisen, Erste, Intesa SP, Société Générale, KBC, Unicredit) write a letter to the EC on financial stability concerns in emerging Europe and urge action by host governments. EBRD (copied on the letter), EIB and IFC start to put together a joint action plan, which culminates in a joint declaration on February 27 (see below).

December $23^{\text {rd }} 2008$ - IMF Announces $€ 1.7$ Billion Stand-By Agreement for Latvia, coordinated with the European Commission.

December $17^{\text {th }} 2008$ - The six multinational bank groups meet in Vienna to discuss next steps by the industry. EBRD and EIB are invited.

January $\mathbf{1 6}^{\text {th }} \mathbf{2 0 0 9}$ - IMF approves $€ 402.5$ million Stand-By Arrangement for Serbia

January $23^{\text {rd }} 2009$ - First "Vienna Initiative" meeting at the Austrian Ministry of Finance. It is agreed that the IMF will develop principles of burden sharing between home and hostcountry authorities and banks.

End-January and early February 2009 - Country meetings for coordinated action in Ukraine and Romania, bringing together the key subsidiaries of bank groups with the IMF and other IFIs and, in Ukraine, the government.

February $27^{\text {th }} 2009$ - The heads of EBRD, EIB, and the World Bank Group launch, as part of the VI framework, the Joint IFI Action Plan, offering up to $€ 24.5$ billion of support to systemic banks in the region and lending to the real economy.

March $17^{\text {th }} 2009$ - Second VI meeting. IMF presents a distribution of burden sharing rules between home and host country authorities which is broadly agreed on and to be used during the crisis. Host country responsibilities: prudent macroeconomic policies, support of deposit insurance schemes, and the supply of local currency liquidity irrespective of bank ownership. Parent banks and home country responsibilities: rollover/maintain exposures to the extent possible, recapitalize subsidiaries following stress tests; home county national bank support packages can be used for supporting subsidiaries.

March $15^{\text {th }}$-June $15^{\text {th }} 2009$ - Under the Joint IFI Action Plan the EBRD, EIB, and World Bank Group meet jointly with all 17 main multinational bank groups to assess their needs.

March $26^{\text {th }}-27^{\text {th }} \mathbf{2 0 0 9}$ - First set of parent bank commitment letters signed for Romania and Serbia, at the Joint Vienna Institute, Vienna.

April $2^{\text {th }} 2009$ - Meeting of IFIs and home and host governments during the IMF-World Bank Spring meetings, Washington DC, to take stock and agree on next steps under the VI.

May $4^{\text {th }} \mathbf{2 0 0 9}$ - IMF approves $€ 12.9$ billion Stand-By Arrangement for Romania as part of a EUR 20 billion package of balance of payments support approved by the European Commission.

May $7^{\text {th }} 2009$-EBRD makes investments worth over $€ 400$ million to UniCredit subsidiaries across eight Emerging European countries.

May $15^{\text {th }} 2009$ - Joint IFI Action Plan: Meeting of key parent banks, home and host governments and IFIs during the EBRD Annual Meetings, London.

May $20^{\text {th }} 2009$ - Commitment letter signed for Hungary and Romania in Brussels.

June $22^{\text {nd }} \mathbf{2 0 0 9}$ - Commitment letter signed for Bosnia and Herzegovina in Vienna.

July $\mathbf{8}^{\text {th }} \mathbf{2 0 0 9}-\mathrm{IMF} € 1.52$ billion Stand-By Agreement for Bosnia and Herzegovina. 
July $10^{\text {th }} \mathbf{2 0 0 9}$ - EBRD sets up a $€ 220$ million financing facility to the Hungarian subsidiaries of OTP Bank and $€ 100$ million to Erste Bank.

July $\mathbf{2 9}^{\text {th }} \mathbf{2 0 0 9}$ - EBRD announces investment of $€ 400$ million in the subsidiaries of Société Générale.

September $14^{\text {th }} 2009$ - Parent bank commitment letter signed for Latvia in Stockholm.

September $23^{\text {rd }} \mathbf{2 0 0 9}$ - EBRD approves a $€ 150$ million financing package to Raiffeisen Bank subsidiaries in Ukraine, Romania, and Russia.

September $24^{\text {th }} 2009$ - First 'horizontal' Full-Forum meeting of the Vienna Initiative in Brussels. Discussion of deleveraging and recapitalization needs - first signal of moving out of the systemic risk phase. Participants: 17 parent bank groups, their home and host supervisors and fiscal authorities, IMF, EC, EBRD, EIB, WB, ECB, CEBS.

October $5^{\text {th }} 2009$ - Meeting with CEOs of parent bank groups, home and host governments and heads of IFIs at the IMF-World Bank Annual Meetings, Istanbul. Joint Progress Report issued by the Joint IFI Action Plan participants (EBRD, EIB, WB).

November 18-19 2009 - Follow-up meetings with parent banks for Romania and Hungary in Brussels. Start of discussions with banks on addressing the vulnerability of foreign exchange (FX) exposures.

January $18^{\text {th }} 2010$ - Coordination meeting with the IMF, World Bank, EIB, EC in Vienna. Shift from crisis management to addressing the region's vulnerabilities (lack of local capital markets, FX exposures) and the legacy of the crisis (balance sheet clean-up, distressed asset management).

February $25^{\text {th }} 2010$ - EBRD provides a $€ 100$ million financing package to Intesa Sanpaolo subsidiaries in Bosnia and Herzegovina, Serbia and Hungary.

February $\mathbf{2 6}^{\text {th }} \mathbf{2 0 1 0}$ - Follow-up meetings on Serbia (with exposure commitments relaxed on the back of good macroeconomic adjustment and recovery) and Bosnia in Vienna.

March 18-19' 2010 - Second 'horizontal' Full-forum VI meeting in Athens. Agreement to set up working groups on local currency market development and on the absorption of EU funds. Participants: 20 bank groups, their home and host supervisors and fiscal authorities, IMF, EC, EBRD, EIB, WB, ECB, and CEBS.

May $4^{\text {th }}$, July $8^{\text {th }}$, and November $10^{\text {th }} 2010$ - Meetings of the working group on local currency development under the Vienna Initiative at the EBRD in London.

May $9^{\text {th }} 2010$ - IMF approves $€ 30$ billion Stand-By Arrangement for Greece.

June $17^{\text {th }} 2010$ - Information session and meeting on the absorption of EU funds in Sofia.

July $22^{\text {nd }} \mathbf{2 0 1 0}$ - Follow-up Vienna parent bank meeting on Romania and Hungary.

July $26^{\text {th }}$-August $4^{\text {th }}-$ Joint Commission-IMF-WB mission to Romania to discuss measures to accelerate the absorption of EU structural funds.

October $4^{\text {th }} 2010$ - EBRD extends just under $€ 1$ billion of financing to subsidiaries of Piraeus Bank, National Bank of Greece, Alpha Bank, and EFG Eurobank.

October $6^{\text {th }} 2010$ - Progress Report on implementation of the Joint IFI Action Plan.

End-2010 - Expiry of the Vienna Initiative Joint IFI Action Plan.

March 2011 - Final Report on implementation of the Joint IFI Action Plan.

March $17^{\text {th }}-\mathbf{1 8}^{\text {th }} \mathbf{2 0 1 1}$ - Third 'horizontal' full forum meeting under the VI in Brussels to evaluate and consider recommendations of the two working groups.

March 17 2011 - Follow-up meetings in Brussels with parent banks on Romania. 